\title{
Controls on dryland mountain landscape development along the NW Saharan desert margin: Insights from Quaternary river terrace sequences (Dadès River, south-central High Atlas, Morocco)
}

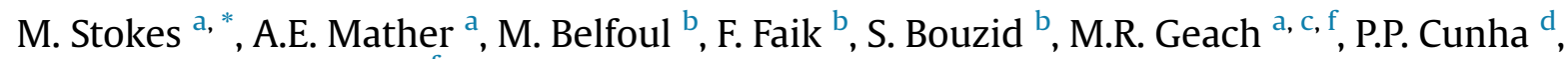 \\ S.J. Boulton ${ }^{\mathrm{a}}$, C. Thiel ${ }^{\mathrm{e}, \mathrm{f}}$ \\ ${ }^{a}$ School of Geography, Earth and Environmental Sciences, Plymouth University, Drake Circus, Plymouth, Devon, PL4 8AA, UK \\ b Structural Geology and Thematic Mapping Laboratory, Earth Sciences Department, Faculty of Science, Ibn Zohr University, PO Box 8106, Hay Dakhla, \\ Agadir, 80000, Morocco \\ c ATKINS, Woodcote Grove, Ashley Road, Epsom, KT18 5BW, UK \\ ${ }^{\mathrm{d}}$ Marine and Environmental Sciences Centre, Department of Earth Sciences, Universidade de Coimbra, Coimbra, Portugal \\ e Leibniz-Institut für Angewandte Geophysik, Stilleweg 2, 30655, Hannover, Germany \\ ${ }^{\mathrm{f}}$ Nordic Laboratory for Luminescence Dating, Aarhus University, and Centre for Nuclear Technologies, Technical University of Denmark (DTU), Risø Campus, \\ Denmark
}

\section{A R T I C L E I N F O}

\section{Article history:}

Received 23 December 2016

Received in revised form

13 April 2017

Accepted 23 April 2017

Available online 8 May 2017

\section{Keywords:}

Pleistocene

Climate dynamics

Paleogeography

Africa

Fluvial geomorphology

Optical methods

\begin{abstract}
A B S T R A C T
This study documents river terraces from upstream reaches of the Dadès River, a major fluvial system draining the south-central High Atlas Mountains. Terraces occur as straths with bedrock bases positioned at $10 \mathrm{~m}$ altitudinal intervals up to $40 \mathrm{~m}$ (T1-T5) above the valley floor, becoming less common between 50 and $140 \mathrm{~m}$. The rock strength, stratigraphy and structure of the mountain belt influences terrace distribution. Terraces are absent in river gorges of structurally thickened limestone; whilst welldeveloped, laterally continuous terraces (T1-T4) form along wide valleys occupying syncline structures dominated by weaker interbedded limestone-mudstone. Terrace staircases develop in confined canyons associated with weaker lithologies and influence from structural dip and stratigraphic configuration.

Terraces comprise a bedrock erosion surface overlain by fluvial conglomerates, rare overbank sands and colluvium. This sequence with some OSL/IRSL age control, suggests terrace formation over a $100 \mathrm{ka}$ climate cycle with valley floor aggradation during full glacials and incision during glacial-interglacial transitions. This integrates with other archives (e.g. lakes, glaciers, dunes), appearing typical of landscape development along the NW Saharan margin south of the High Atlas, and similar to patterns in the western-southern Mediterranean. The $100 \mathrm{ka}$ climate cycle relationship suggests that the terrace sequence documents Late-Middle Pleistocene landscape development.

Consistent altitudinal spacing of terraces and their distribution throughout the orogen suggests sustained base-level lowering linked to uplift-exhumation of the High Atlas. Low incision rates $(<0.2 \mathrm{~mm}$ $\mathrm{a}^{-1}$ ) and general absence of terrace deformation suggests dominance of isostatically driven base-level lowering with relief generation being Early Pleistocene or older.
\end{abstract}

(๔) 2017 Elsevier Ltd. All rights reserved.

\section{Introduction}

River terraces are bodies of fluvial sediment with a step-like margin and flat topped surface that grade topographically towards a valley centre and in a downstream direction (Stokes et al., 2012a). They are commonly preserved along river valley margins around the

\footnotetext{
* Corresponding author.

E-mail address: mstokes@plymouth.ac.uk (M. Stokes).
}

world and are considered to have regional lithostratigraphic importance (Bridgland and Westaway, 2008a,b; 2014). A terrace forms when a river incises, abandoning the former floodplain and channel belt (Leopold et al., 1964). Successive periods of fluvial sediment aggradation, river incision and floodplain-channel abandonment can form inset river terrace staircases (Starkel, 2003). The fluvial sedimentation is generally a function of climate-related sediment supply and flood regime, whilst river incision is determined by base-level lowering, normally driven by combinations of tectonics, climate and eustacy (e.g. Bridgland and Westaway, 2008a; 
Vandenberghe, 2015). Global database compilations of river terrace research have highlighted the importance of terraces as archives of Late Cenozoic (mainly Quaternary) environmental change and their relationship to unravelling the development of topographic relief (Bridgland and Westaway, 2008a,b; 2014). Much of this research is focussed on large, mid latitude northern hemisphere river systems that have evolved under fluctuating glacial, periglacial and humid climatic conditions due to their ice sheet proximity and connectivity. With few exceptions (see Bridgland and Westaway, 2008a and references therein), there is a notable research gap from lower latitude regions where fluvial systems have evolved in environments with negligible-minimal direct ice sheet influence under drier continental conditions. One such area is NW Africa and its inland arid region south of the High Atlas Mountains (Fig. 1).

The NW Saharan Desert margin is bordered by the $3-4 \mathrm{~km}$ relief of the High Atlas Mountains of Morocco. Its topography, and the lower relief $\sim 2 \mathrm{~km}$ Anti-Atlas Mountains to the south (Fig. 1), marks the southern limits of ongoing Alpine tectonic collision between Africa and Europe (Dewey et al., 1989) and is a key area of climate interchanges between the Atlantic, Mediterranean and continental low latitude regions of Central-West Africa (Tjallingii et al., 2008). The mountain landscape origins relate to accelerated PlioQuaternary uplift (Frizon de Lamotte et al., 2000) and global climate cooling and fluctuations throughout the Quaternary (Plaziat et al., 2008). Quaternary sediments and landforms occur throughout the region (Plaziat et al., 2008) but river terrace research is limited, being geographically restricted to coastal areas of the Anti-Atlas (e.g. Weisrock et al., 2006) and localised parts of the northern High Atlas (Delcaillau et al., 2016). Coastal river terrace studies are either regional treatments, using river-marine terraces for numerical uplift modelling (e.g. Westaway et al., 2009) or are localised studies high resolution dating studies of a single Late Pleistocene terrace level site for detailed climatic insights (e.g. Weisrock et al., 2006). These Atlantic draining rivers have a strong climate-eustatic base level control, have developed in low mountain relief and are influenced from humid Atlantic weather. However, these coastal systems are not typical of inland, where drainage has evolved under considerably drier continental climatic conditions, greater relief variability and absence of eustatic base level control. The southern flanks of the High Atlas provide an excellent area to study river terraces and their role for unravelling Quaternary fluvial landscape development typical of the dryland continental interior of NW Africa. Here, rivers are 1) sourced from some of the highest mountain relief, 2) are routed southwards from mountain through to lower lying desert climatic regions and 3 ) cross all of the key tectonic components of the High Atlas orogenic system.

In this study we focus on a 60-km-long upstream reach of the Dadès River (Fig. 1), a principal river system draining the south-central High Atlas in the characteristic dryland continental interior of NW Africa. The terraces are used to explore the interplay of geological, climate and tectonic base level controls on Quaternary fluvial landscape development. The relationship of the terrace sequence to the rock strength, structure and stratigraphic sequence of the High Atlas orogen is assessed as a passive geological control on terrace formation. Terrace-climate relationships are examined using an OSL/IRSL dated terrace sediment sequence, providing insights into the timing of fluvial aggradation and incision patterns and their relationship to a $100 \mathrm{ka}$ climate cycle. The terrace sequence is then used to explore spatial and temporal patterns of base-level lowering through incision rate quantification and its relationship to the timing and mechanisms of tectonic relief generation of the High Atlas orogen.

\section{Geological and geomorphological background}

\subsection{Regional geology and drainage evolution}

The Dadès River is one of the larger drainage systems in NW Africa forming the principal perennial river that drains the southcentral High Atlas Mountains of Morocco (Fig. 1B). On entering the Ouarzazate Basin, the Dadès River flows westwards along the northern margin of the Anti-Atlas. At Ouarzazate town, the Dadès River joins the Draa River, turning SE with routing across the AntiAtlas through the Draa Gorge before turning WSW to join the Atlantic Ocean.

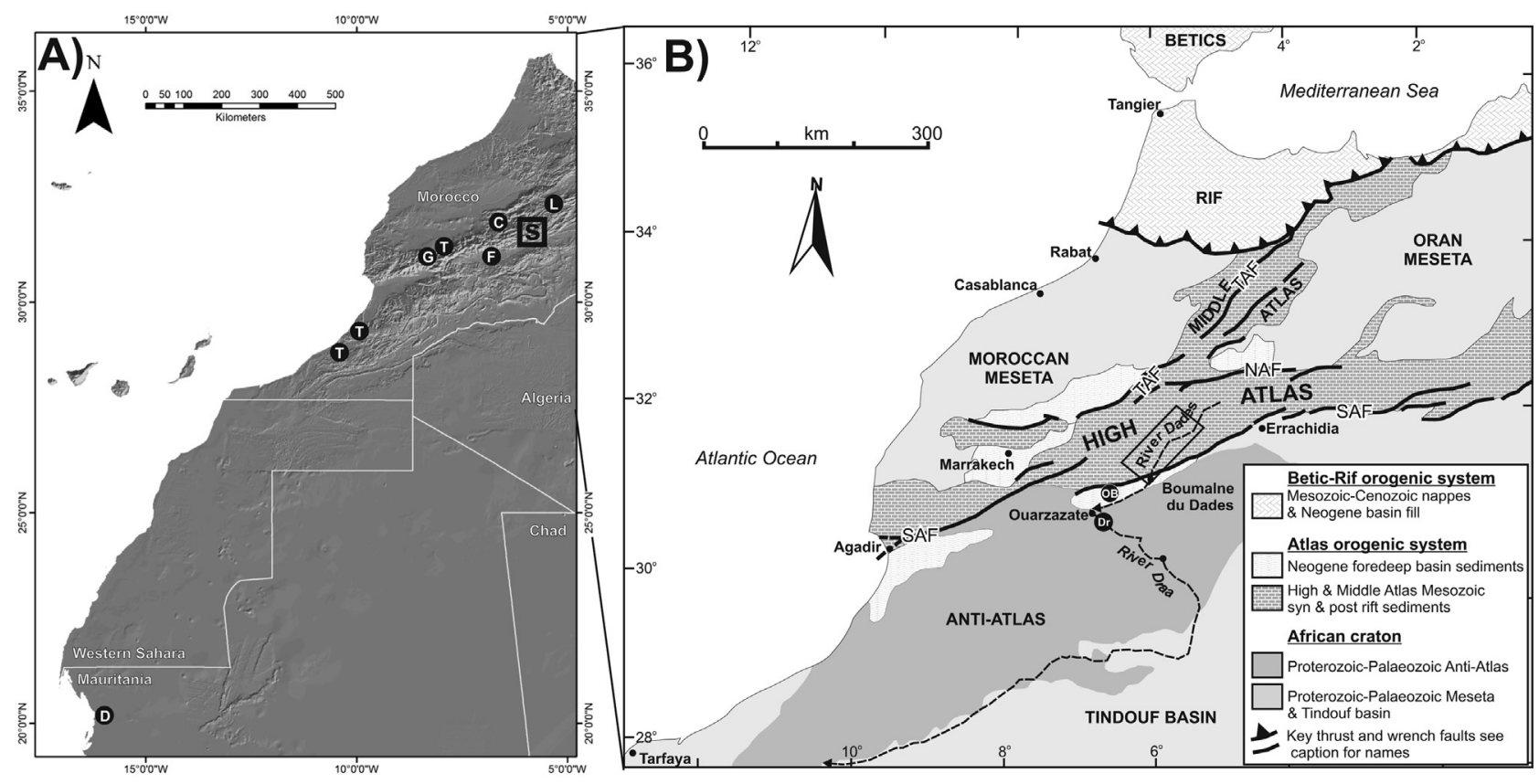

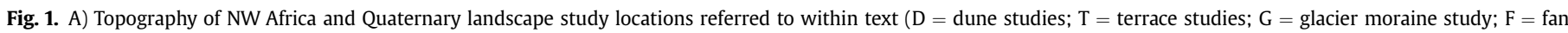

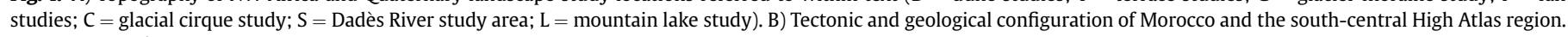

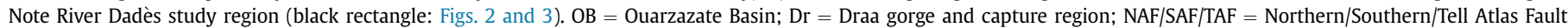
systems. Modified from Michard (1976) and Carte Géologique du Maroc (1985). 
This drainage configuration relates to the long term tectonic development of NW Africa. The High Atlas is an ENE-WSW oriented Alpine orogenic system formed by African-European plate suturing (Dewey et al., 1989; Frizon de Lamotte et al., 2008). Relief generation of $2-4 \mathrm{~km}$ has involved the inversion of a Mesozoic intracontinental rift system by regional thrust faulting and folding (e.g. Gomez et al., 2000) and thermal-related isostatic uplift related to a mantle plume underlying the High Atlas (e.g. Missenard et al., 2006). The mountain belt displays common characteristics of a collisional orogenic system (Figs. 1B and 2): a high relief 'axial zone', bordered by thrust front (Northern and Southern Atlas faults [NAF/ $\mathrm{SAF}]$ ) and peripheral foreland basins around the relief margins (Chellai and Perriaux, 1996; El Harfi et al., 2001). The stages and timing of High Atlas relief generation are debated but generally considered to have occurred in two stages during the Early and Late Cenozoic (Frizon de Lamotte et al., 2000).

Analysis of the High Atlas drainage pattern by Babault et al. (2012) describes rivers that are longitudinal (strike-orientated) or transverse to the mountain belt structure. This research suggests that early drainage is inherited from growing upper crust fault-fold structures, with later drainage development configured to amplified N-S regional slopes as topography grows. The modern Dadès River is oblique to the orogen structure, suggesting it is a longer lived longitudinal drainage system (Babault et al., 2012) but one that contains large scale knick zones linked to more recent PlioQuaternary uplift and relief generation (Boulton et al., 2014).

At continental scale, the modern Dadès-Draa system (Fig. 1B) is related to capture of the internally drained Ouarzazate Basin by an
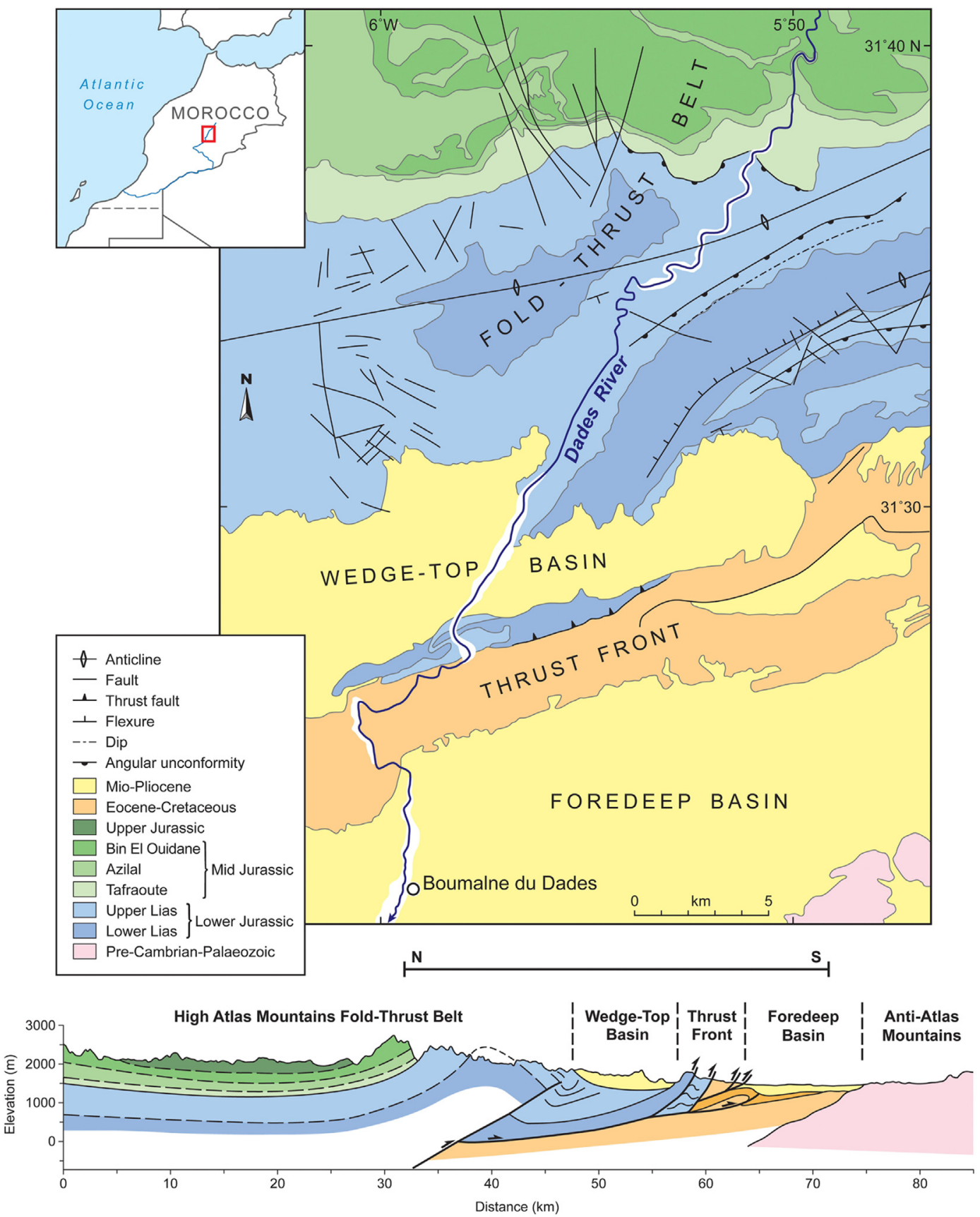

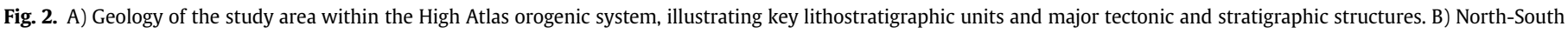
orogenic cross-section. Map and cross-section modified from Carte Géologique du Maroc (1975, 1990; 1993). See Table 1 for stratigraphic and lithologic information. 
Anti-Atlas drainage (Stäblein, 1988). The capture is probably a Middle-Late Pleistocene occurrence based upon fan surface dating from sites north of Ouarzazate town (Arboleya et al., 2008).

\subsection{Geology and geomorphology of the Dadès River}

The headwaters of the modern Dadès River lie at altitudes of 2800-3400 $\mathrm{m}$ (above sea level), with the river entering the Ouarzazate Basin at $\sim 1550 \mathrm{~m}$ (Fig. 3A). The study area (Fig. 3B) encompasses key geological and morphological components of the High Atlas orogenic system (Figs. 2 and 3): 1) high relief (3400-2000 m) fold-thrust belt (FTB), 2) intermediate relief (1900-1600 m) wedge-top basin (WTB), 3) intermediate relief (1900-1600 m) thrust front (TF) and 4) low relief (1600-1500 m) foredeep basin (FB) (orogen terminology sensu DeCelles and Giles, 1996).

The FTB forms the mid to upstream parts of the study area (Fig. 3). Jurassic marine limestone and mudstone lithologies are dominant (Carte Géologique du Maroc, 1990, 1993), corresponding to a Mesozoic rift system that forms the central-eastern High Atlas (Warme, 1988). This bedrock is affected by a series of regional fold and thrust fault structures (Fig. 2). In the upstream FTB the Dadès River cuts through the SE limb of a symmetric open anticline in a series of deeply incised (>100 m depth) high sinuosity canyons (Figs. 2, 3 and 4A). Downstream, the folding changes to an asymmetric syncline with the Dadès River routed southwest along the fold axis in an open valley configured by the syncline (Figs. 2, 3 and 4B). A route deviation to the southeast occurs at the Tarhía n' Dadès gorge (Figs. 2, 3 and 4C) where the Dadès River cuts a short $0.5 \mathrm{~km}$ long, $150 \mathrm{~m}$ deep and $20-50 \mathrm{~m}$ wide route through a Lower Jurassic limestone ridge (Stokes et al., 2008). In the downstream distal part of the FTB, thrust faulting has structurally thickened Lower Jurassic limestones causing the Dadès River to cut a deeply incised (>200 m), $\sim \mathrm{km}$ long and $20-100 \mathrm{~m}$ wide gorge, the Dadès Gorge (Figs. 2, 3 and 4D; Stokes et al., 2008).

The Dadès River emerges from the Dadès Gorge into the Aït Sedratt WTB (Figs. 2, 3 and 4E). Plio-Quaternary terrestrial fan and fluvial conglomerates are organised into a syncline that has developed between the FTB and the TF (Carte Géologique du Maroc, 1990, 1993). Sediment provenance, palaeocurrents and stratigraphic-structural organisation suggests a complex FTB transverse and parallel palaeo-drainage routing influenced by thrust faulting and folding (Cavini, 2012), corresponding in part to an ancestral Dadès River. The modern Dadès River is routed

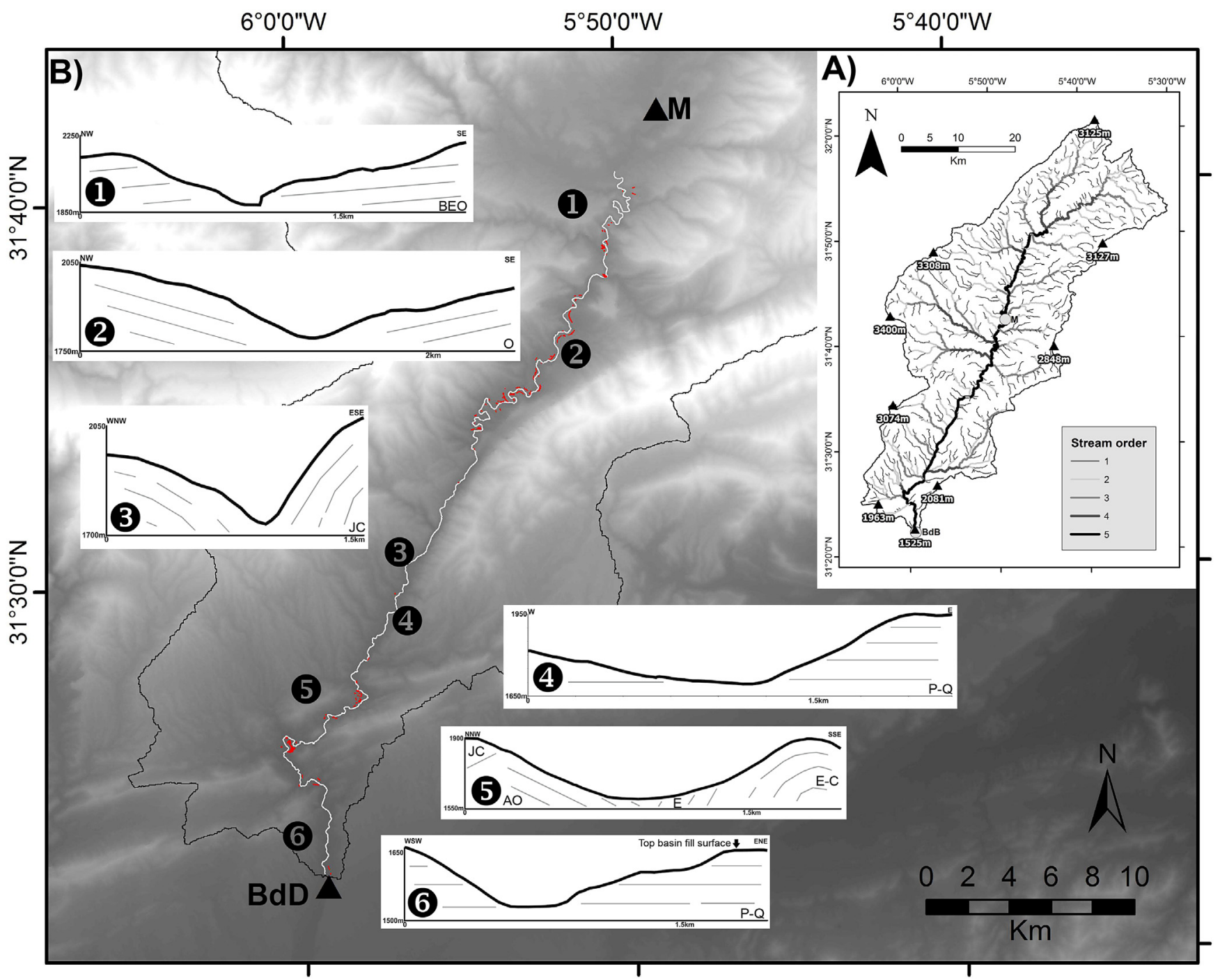

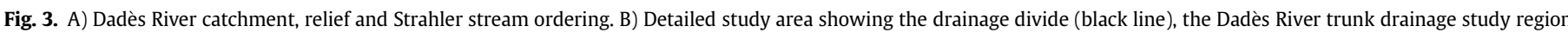

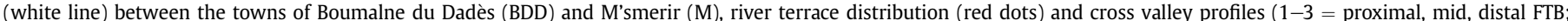

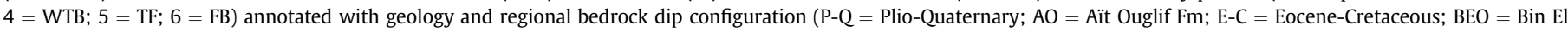
Ouidane Fm, $\mathrm{O}=$ Ouchbis Fm, JC = Jbel Choucht Fm: See Fig. 2 and Table 1). 
southwest, transverse to the WTB in a relatively open asymmetric valley flanked by high cliffs on western banks and lower slopes/ cliffs on eastern banks (Figs. 3B and 4E).

In the TF region, the Dadès River passes through a structurally complex ENE-WSW striking, southwards verging folded and oblique thrust faulted sequence of Mesozoic-Cenozoic lithologies (Carte Géologique du Maroc, 1975; Tesón and Teixell, 2008). The river displays marked orientation changes as it passes through the TF region, showing a dominant configuration to the ENE-WSW strike of deformation, with shorter NNW-SSE valley reaches that are transverse to the TF strike (Figs. 2 and 3B). The strike and transverse orientated valleys are relatively open (Fig. $4 \mathrm{~F}$ ) but short gorge reaches exist where the river routes through Jurassic and Palaeogene limestones (Fig. 4G). Cross-sections and stratigraphic-structural analyses by Tesón and Teixell (2008) suggest that the TF region has undergone low rate $\left(0.3 \mathrm{~mm} / \mathrm{a}^{-1}\right)$ tectonic shortening of $7-8 \mathrm{~km}$.

Finally, the Dadès River emerges from the TF passing southwards into the (Ouarzazate) FB (Figs. 2, 3 and 4H). Here, PlioQuaternary terrestrial fan and fluvial conglomerates form the dominant lithology, with some stratigraphic affinity to similar

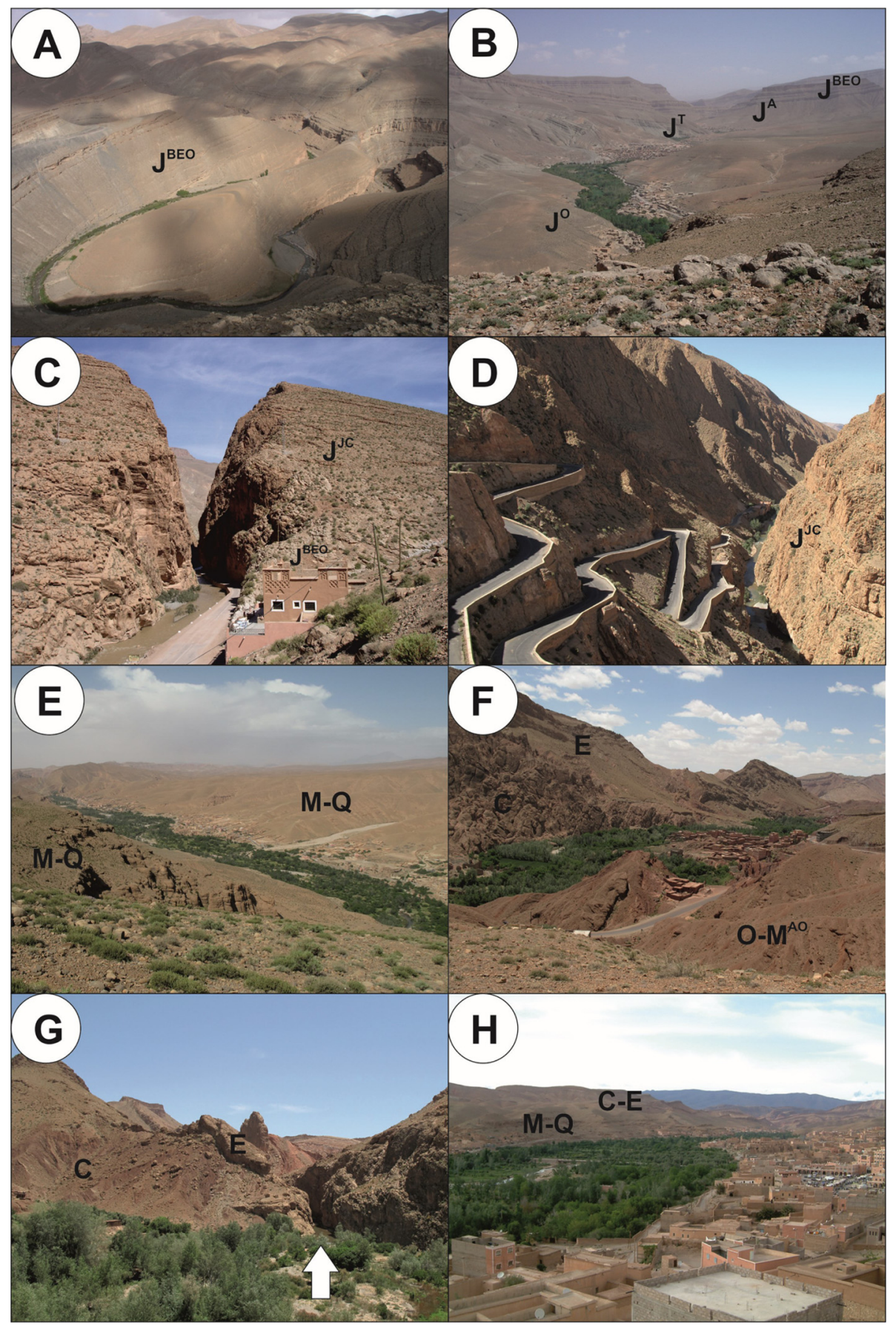

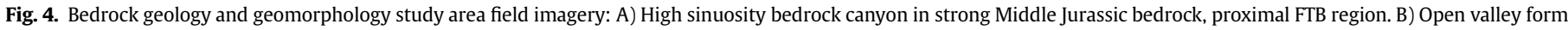

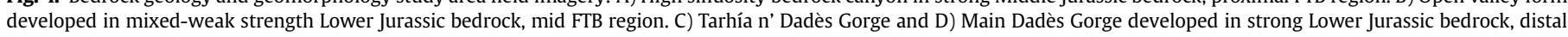

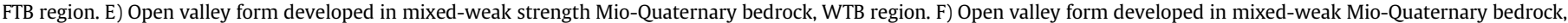

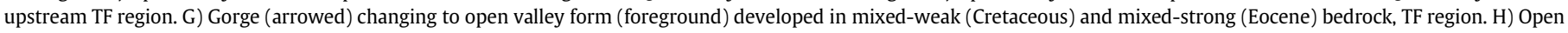
valley form developed in mixed-weak Mio-Quaternary bedrock, FB region. See Table 1 for stratigraphy, lithology and rock strength characteristics and notation. 
sediments in the WTB (Cavini, 2012). The sediments form a top surface $\sim 100 \mathrm{~m}$ above the Dadès River valley floor (Fig. 3B), with the surface revealing relict fan-shaped morphologies fed from drainage outlets along the TF/FB margin. Further west in central and western parts of the Ouarzazate Basin, the surface is incised forming a stepped landscape with up to 5 inset fan/terrace surfaces (Görler et al., 1988; Stäblein, 1988; Arboleya et al., 2008). Some higherolder surfaces display folding and fault scarps (Sébrier et al., 2006; Arboleya et al., 2008) suggesting Quaternary deformation. Seismic activity is infrequent and low magnitude, with historical shallow earthquakes of magnitude $<4.9$ distributed throughout the TF/FB margin regions (Medina and Cherkaoui, 1991).

\subsection{Quaternary-recent characteristics of the Dadès River and surrounding region}

The modern Dadès River is a perennial 5th order trunk drainage (Fig. 3A) fed by ephemeral tributaries (Stokes and Mather, 2015). The modern channel occupies a highly sinuous valley, incised by $<3 \mathrm{~m}$ into a flat up to $500 \mathrm{~m}$ wide alluvial floodplain of weakly cemented gravels capped by sands and silts. Canyon and gorge reaches often lack the alluvial floodplain instead comprising bedrock reaches with sometimes thin and transient alluvial covers. Flood hydrology is influenced by a semi-arid mountain climate with a marked altitudinal zonation where annual precipitation varies from $200 \mathrm{~mm}$ upstream (M'smerir village) to $150 \mathrm{~mm}$ downstream (Boumalne du Dadès town) (Schulz et al., 2008; Dłużewski et al., 2013) (Fig. 3). Average daily discharges are $33.3 \mathrm{~m}^{3} / \mathrm{s}$ but with seasonal variation linked to annual winter-spring precipitation in drainage divide regions derived from Atlantic low pressure incursions and rarer convective storm events from the tropics (e.g. Fink and Knippertz, 2003). The ephemeral tributaries commonly store and supply large volumes of coarse clastic sediment to alluvial fans in the Dadès River valley dependent upon the tributary catchment bedrock lithology, stratigraphy and structure. The fans build out onto the valley floor and are often eroded through interaction with low frequency-high magnitude flooding (Stokes and Mather, 2015). Bedrock weathering and sediment supply are further enhanced by the absence of vegetation cover.

Throughout the study area, alluvial terraces are observed along the sides of the Dadès valley and its larger tributaries. Their only documentation is on recent geological maps (e.g. Carte Géologique du Maroc, 1993) where up to 5 levels (q1-q5) are intermittently recorded using the classical stratigraphic subdivision nomenclature (Plaziat et al., 2008): Younger Quaternary = Soltanien [q1]; Middle Quaternary = Tensiftien [q2]; Older Quaternary = Amirien [q3], Saletien [q4], Moulouyen [q5]. The maps lack detail on mapping procedure, height information, age assignment and any terrace environmental significance. During the Quaternary, arid climate conditions dominate, fluctuating between cool and dry glacials and warm and dry interglacials (Lamb et al., 1994; Valero-Garcés et al., 1998). Despite the aridity, periods of humidity with elevated precipitation existed, becoming regionally elevated during the major climate transitions (Tjallingii et al., 2008). During the glacials high relief areas (2-4 km) saw plateau icefield, valley glacier development, periglacial activity (Wiche, 1953; Hughes et al., 2011) and fluctuating high mountain lake levels (Lamb et al., 1994; Valero-Garcés et al., 1998); contrasting with enhanced aeolian dune activity in low relief and lower latitude western Sahara Desert regions (Lancaster et al., 2002).

\section{Approach and methods}

\subsection{Terrace mapping, stratigraphy and sedimentology}

River terraces were analysed using integrated field and remote sensing approaches in-between the towns of Boumalne du Dadès (downstream) and M'smerir (upstream) (Fig. 3). Remote sensing utilised 1 arc second SRTM derived digital elevation data, Google Earth imagery, topographic and geological maps collectively visualised and interrogated in Arc GIS.

River terraces were identified using standard morphological and geological criteria (Stokes et al., 2012a; Mather et al., 2017). Terrace surfaces were often unclear due to burial by slope/fan deposits but valley side erosion commonly revealed a flat to gently dipping downstream terrace surface contact with overlying slope material. Terrace risers were normally steep and cliff-like, whilst terrace bases revealed sharp lithological contrasts between the fluvial conglomerate and underlying bedrock. Contacts between conglomerates and overlying slope deposits utilised differences in sediment textures, fabrics and stratigraphy (Mather et al., 2017).

Terraces were mapped using a Trimble Geo-XH GPS to record breaks and changes in slope associated with inner valley terrace margins (i.e. closest to the modern river). Outer valley terrace margins were normally estimated/extrapolated using slope morphology differences between the bedrock geology, the slope deposit and the terrace. Terrace heights were surveyed using a Trupulse 360B laser range finder, recording the elevation of the lowest point of the terrace base above the modern river, in accordance with other strath terrace studies in mountain belt settings (e.g. Stokes et al., 2012b). Terrace bases were unclear in areas of Plio-Quaternary basin fill (e.g. FB and WTB settings) due to similarities in sediment textures, fabric and structures. Here, terrace heights were based on survey estimates using differences in slope geomorphology (e.g. Mather et al., 2017). The locations and elevations of the terraces, together with those of the modern river long profile were compiled into an Excel database (Supplementary Information) and represented as a scatterplot terrace height-range diagram (Fig. 5). Using the database and the height-range diagram, a terrace stratigraphic framework was constructed. Normally, a terrace stratigraphic framework is constructed using combinations of variables including: sedimentology, soils, terrace height, provenance, desert pavement etc. (e.g. Meikle et al., 2010; Stokes et al., 2012b). Here, the terrace stratigraphy was constructed using terrace base elevation and assuming the simplest palaeo-profile fit, since all other variables showed insufficient contrast or are absent between levels. Terrace stratigraphic nomenclature uses a letter and numbering system with $\mathrm{T} 1$ the lowest and youngest level, with subsequent higher altitude/older terraces levels corresponding to T2 and T3 etc. Terraces above T6 (50 m above modern channel) are rare fragmentary occurrences that make correlation difficult. These levels are referred to using height only but the terrace numbering system allows future studies to assign further levels (e.g. T7 etc.) if required.

Field mapping enabled type localities to be selected for detailed study, including sites with 1) well-preserved river terrace staircases in contrasting geological-geomorphological contexts, 2) clear and representative internal terrace stratigraphy and sedimentology, 3) suitable material for OSL sampling and 4) evidence for tectonic deformation. Sites with clear and representative internal terrace stratigraphy and sedimentology were described and logged using sediment facies analysis (Miall, 1978) to enable sedimentary process and environment interpretations.

\subsection{Terrace dating}

Terrace chronology was established using OSL/IRSL dating of quartz and feldspar, a technique routinely used for Quaternary river terrace studies (e.g. Martins et al., 2010). Sands suitable for OSL/IRSL dating were extremely rare and were restricted to the T2 terrace ( $10 \mathrm{~m}$ above the modern river) located only in the upstream study area within mid and proximal parts of the FTB region. Three sites were sampled over a $10 \mathrm{~km}$ distance (Fig. 5; Supplementary 
Information) to ensure stratigraphic continuity and to test the temporal consistency of the T2 terrace age results. Sampling targeted fluvial sands that capped the coarse grained fluvial gravels (Fig. 9). These sands reflect overbank areas elevated adjacent to the active channel (Section 5). After logging the sections, sampling locations were prepared by removing weathered surface sediment under black out conditions. Steel tubes $(\sim 30 \times 10 \mathrm{~cm})$ were hammered into the sand units with tube ends sealed on removal, all under blackout conditions. Host sediment water content was visually estimated in the field. A bulk sand sample was obtained for laboratory dosimetry measurements.

The tube (180-250 $\mu \mathrm{m}$ sand fraction) and bulk samples were prepared for laboratory dosimetry measurement using standard chemical cleaning preparation steps, followed by radionuclide concentration measurement with final dose rate calculations using the conversions and calculations of Prescott and Hutton (1995) and Adamiec and Aïtken (1998) (Supplementary Information). A nominal water content of $5 \pm 4 \%$ was used based on field estimates and laboratory derived saturation moisture contents. Luminescence measurements were made using a Risø OSL reader (DA-20). Quartz luminescence followed the SAR protocol (Murray and Wintle, 2000) involving natural quartz purity dose checks (Duller, 2003) and preliminary preheat plateau tests (Supplementary Information). Feldspar luminescence followed the infrared stimulated luminescence (IRSL) approach (Buylaert et al., 2012), measuring normal and post IRSL signals at low and high temperatures (e.g. IR 50 and pIRIR 290). The SAR protocol (Thiel et al., 2011; Buylaert et al., 2012) was used for K-feldspar IRSL signal measurements and testing (Supplementary Information).

\subsection{Terrace-rock strength relationships}

The relationship between rock strength and terrace distribution was assessed using published geological maps and insitu field strength testing. Within the study area, the Mesozoic and Cenozoic bedrock comprises a range of different sedimentary lithologies that possess different strength properties related to lithology textures (granular vs crystalline), cementation and discontinuity (joints, fractures, bedding, etc.) characteristics. Following Stokes and Mather (2015) two strength-lithology types were identified based upon (i) qualitative strength properties (above) and (ii) quantitative in situ mass strength measurements using a Schmidt hammer (Goudie, 2006):

Type 1 - massive crystalline limestone or cemented clastic sediments (conglomerates or sandstones) with Schmidt hammer values of 40-60. Rock surfaces display minimal discolouration. Rock weathers/erodes into decimetre blocks, slabs or large clasts.

Type 2 - poorly cemented sandstone, siltstone, and mudstone with Schmidt hammer values of $<30$. Rock surfaces are discoloured, and rock mass possesses a well-developed fissile fabric conducive to granular weathering characterised by marked disintegration.

Stratigraphic units dominated by Type 1 or 2 lithologies were classified respectively as 'Strong' or 'Weak'. Where a mixture of Type 1 and 2 lithologies occurred, then rock strength was classified as 'Mixed-Strong' or 'Mixed-Weak' depending on the Type 1 vs 2 dominance. Table 1 summarises the stratigraphy, lithology and rock strength relationships and downstream strength variability is plotted graphically alongside river terrace occurrences (Fig. 5).

\section{River terrace distribution}

Terraces were recorded at up to $140 \mathrm{~m}$ above the modern valley floor (Fig. 5). They are generally common features, often as laterally persistent levels along valley sides at up to $50 \mathrm{~m}$ (T6) (Figs. 5 and $6 \mathrm{~A}, \mathrm{~B})$, and then form infrequent fragmented levels and/or isolated occurrences at $\sim 80 \mathrm{~m}$ and $\sim 140 \mathrm{~m}$ (Figs. 5 and $6 \mathrm{C}$ ). The lowest T1

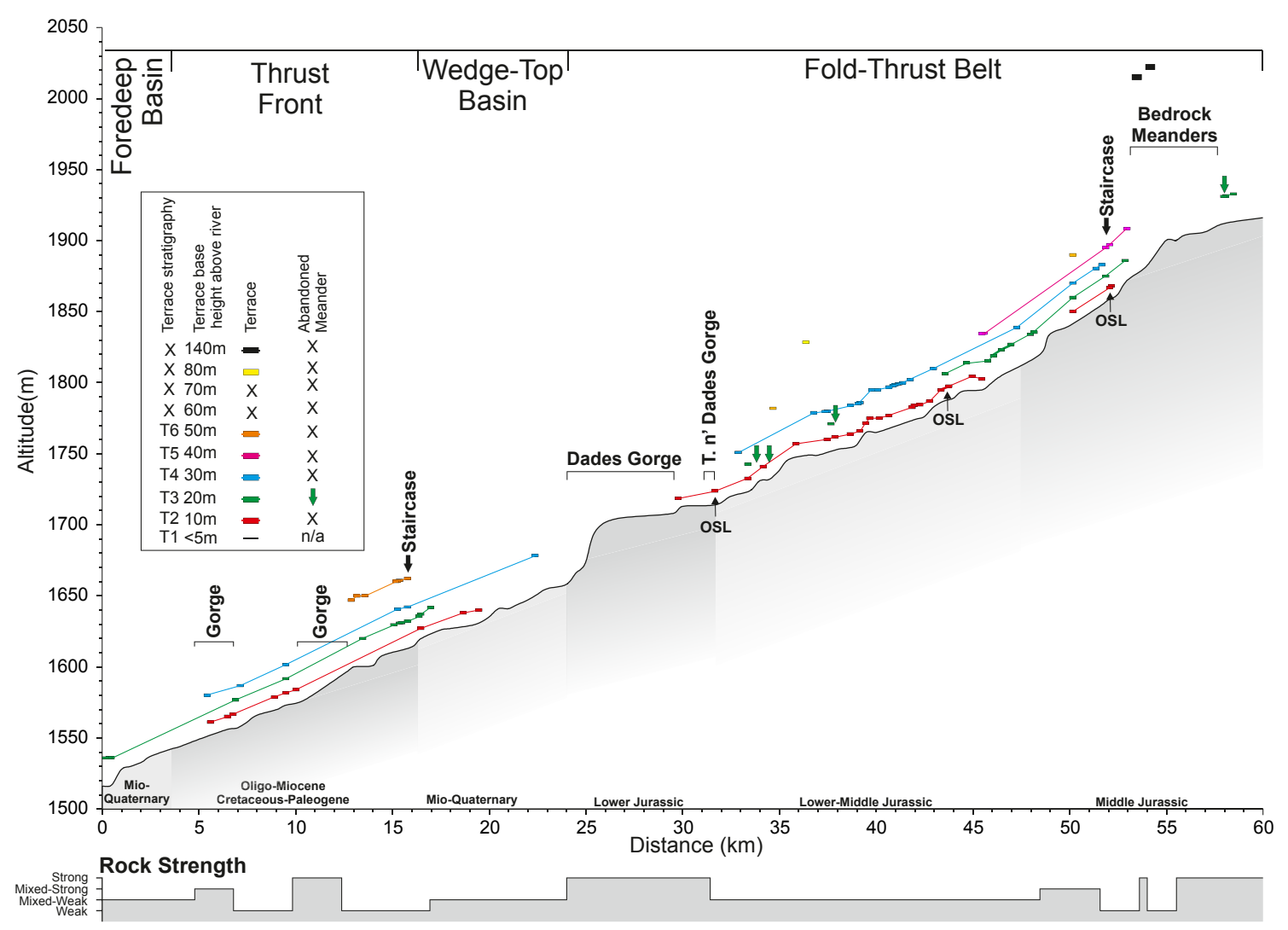

Fig. 5. River terrace, river gorge, bedrock and abandoned meander relationships to the orogenic system, bedrock stratigraphy and strength. 
Table 1

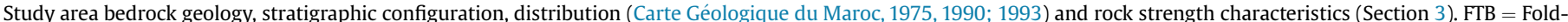

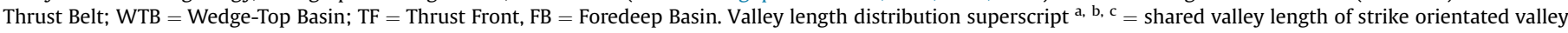
exploiting contact between different stratigraphic units.

\begin{tabular}{|c|c|c|c|c|c|c|c|}
\hline Time & & & Formation name & Lithologies & $\begin{array}{l}\text { Orogen } \\
\text { occurrence }\end{array}$ & $\begin{array}{l}\text { Study area valley } \\
\text { length distribution } \\
(\mathrm{km})\end{array}$ & Rock strength \\
\hline \multirow[t]{3}{*}{ Cenozoic } & \multicolumn{2}{|c|}{ Miocene-Quaternary (M-Q) } & $\begin{array}{l}\text { Aït Kandoula } \\
\text { (AK) }\end{array}$ & $\begin{array}{l}\text { Continental fluvial and fan conglomerate: } \\
\text { cemented carbonate cobbles }\end{array}$ & WTB, FB & 11.88 & Mixed-Weak \\
\hline & \multicolumn{2}{|l|}{ Oligo-Miocene (O-M) } & Ait Ouglif (AO) & $\begin{array}{l}\text { Continental fluvial conglomerate, } \\
\text { sandstone and siltstone }\end{array}$ & TF & $2.1^{\mathrm{b}}$ & Weak \\
\hline & \multicolumn{2}{|l|}{ Eocene (E) } & $\mathrm{n} / \mathrm{a}$ & Continental and marine limestone and marl & $\mathrm{TF}$ & $4.63^{\mathrm{a}}$ & Mixed-Strong \\
\hline \multirow[t]{6}{*}{ Mesozoic } & \multicolumn{2}{|l|}{ Cretaceous (C) } & $\mathrm{n} / \mathrm{a}$ & Continental sandstone, shale and gypsum & $\mathrm{TF}$ & $6.89^{\mathrm{b}}$ & Weak \\
\hline & \multirow[t]{5}{*}{ Jurassic (J) Middle } & Bajocien & $\begin{array}{l}\text { Bin El Ouidane } \\
\text { (BEO) }\end{array}$ & $\begin{array}{l}\text { Marginal marine platform oolitic } \\
\text { limestone and marls }\end{array}$ & FTB & 4.9 & Mixed-Strong \\
\hline & & Aalenien & Azilal (A) & $\begin{array}{l}\text { Continental and marginal marine silts, } \\
\text { marls, sandstone and dolomite }\end{array}$ & FTB & 3.5 & Weak \\
\hline & & Toarcien & Tafraout $(\mathrm{T})$ & $\begin{array}{l}\text { Continental fluvial and marginal marine/coastal } \\
\text { plain marl, silt and sandstone. }\end{array}$ & FTB & 3.2 & Mixed-Strong \\
\hline & & Pliensbachien & $\begin{array}{l}\text { Jbel Choucht } \\
\text { (JC) }\end{array}$ & Massive marine platform limestone. & FTB, TF & $10.56^{\mathrm{a}}$ & Strong \\
\hline & & Pliensbachien & Ouchbis $(\mathrm{O})$ & $\begin{array}{l}\text { Interbedded deep marine rhythmic } \\
\text { limestone and marl. }\end{array}$ & FTB & 17 & Mixed-Weak \\
\hline
\end{tabular}

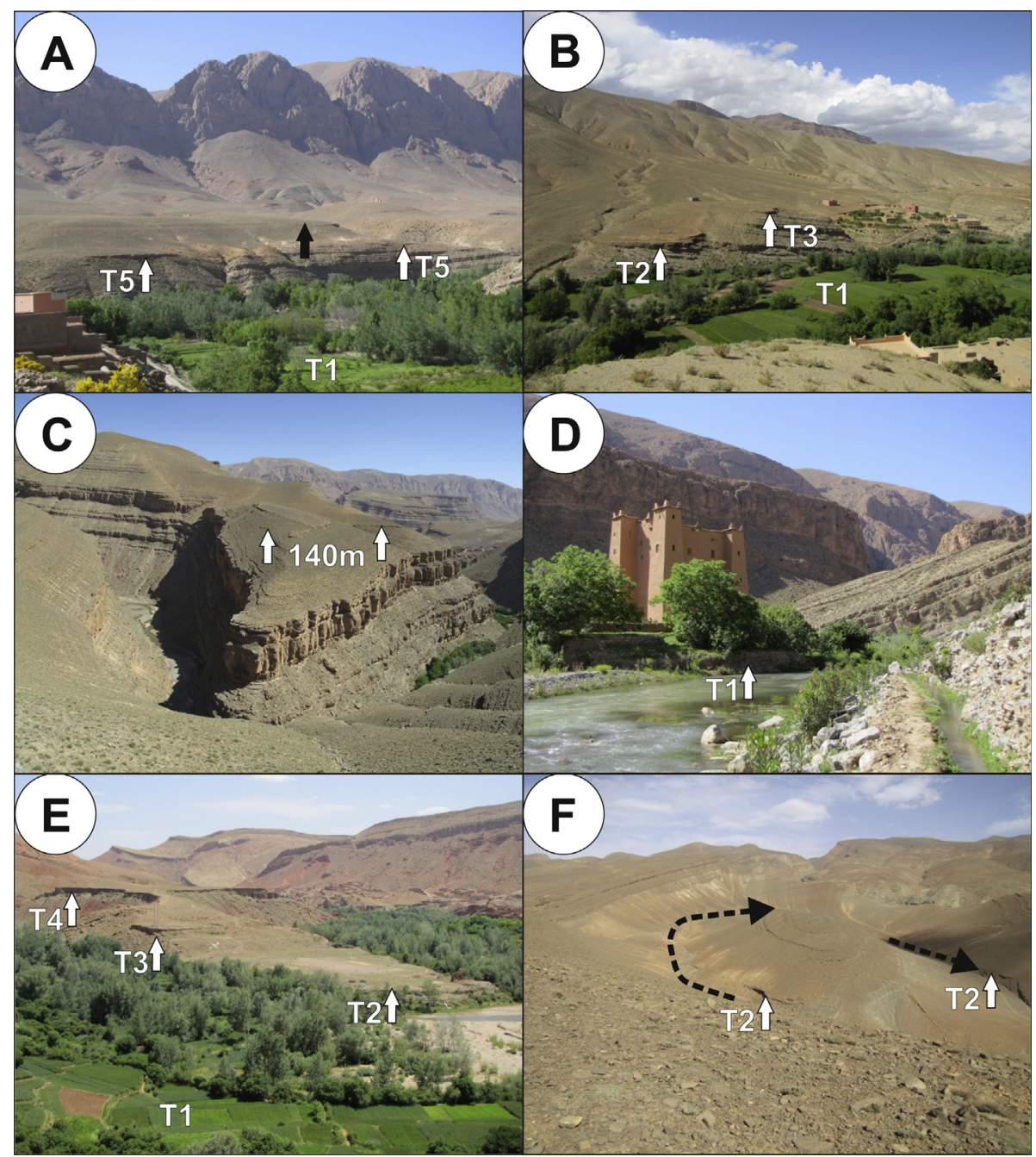

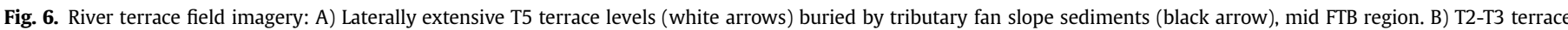

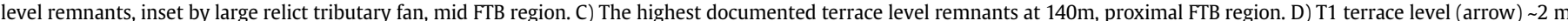

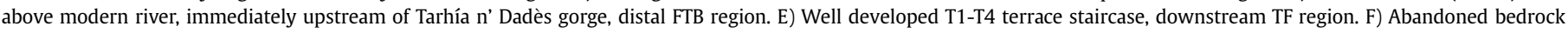
meander containing T2 upstream-downstream terrace remnants buried by locally derived slope deposits, proximal FTB region. 
terrace level is slightly incised $(<3 \mathrm{~m}$ ) by the modern Dadès River and occupies large areas of the valley floor, commonly used for subsistence agriculture (Figs. 5 and 6D). Above T1 there is a consistent vertical spacing of terraces up to $50 \mathrm{~m}$ at $10 \mathrm{~m}$ intervals (T2 to T6) (Fig. 5). The stratigraphic relationship of the higher terrace levels above T6 (e.g. $50 \mathrm{~m}$ ) is unclear and thus lacks correlation in this study. Google Earth and Excel databases of terrace locations, stratigraphy and bedrock geology-strength relationships are provided as Supplementary Information.

Levels T1 to T4 form well preserved, extensive levels throughout much of the FTB region (Fig. 5) where they overlie steeply dipping to flat lying Lower Jurassic limestone-mudstones of the Ouchbis Formation in a wide, open valley (Figs. 3B and 6A,B). In proximal, upstream parts of the FTB there is a progressive increase in limestone as the bedrock geology changes to the Middle Jurassic (Figs. 2 and 4A). Here, terraces form one of the best developed staircases in the study area, comprising T1 to T5 that have developed on a bedrock spur as part of a pronounced valley meander (Figs. 5 and 7). Upstream of this staircase decametre thick limestone units of the Middle Jurassic Bin El Ouidane limestone dominate, with the valley form changing to a high sinuosity knick zone reach of bedrock meanders that lack terraces (Figs. 4A and 6C). Downstream, in the most distal part of the FTB region, terraces are absent from the Dadès and Tarhía n'Dadès Gorges, where vertical fluvial incision and limited valley widening has occurred into strong Lower Jurassic Jbel Coucht limestone (Figs. 4C and D and 5). These gorges form marked lithological knick zones on the modern river profile (Fig. 5 and Boulton et al., 2014). Within the FTB region are four occurrences of km-scale abandoned bedrock meanders (Fig. 5), associated with the T2 level located on the SE side of the river valley. T2 fluvial sediments occur at the upstream entry and downstream exit points of the abandoned meanders (Fig. 6F). The meander cutoffs are infilled with slope colluvium but tributary stream incision through this fill often reveals the terrace and its basal Jurassic bedrock contact.

Within the WTB region terraces are unclear due to the lithological similarity with the Plio-Quaternary basin infill. Slope morphological changes suggest some fragmentary T2 terrace occurrences and an isolated T4 (Fig. 5).

Terraces become more common throughout the TF (Fig. 5). Upstream areas show a well-developed staircase comprising T1 through T4 developed onto steeply dipping Neogene bedrock. Downstream is a more open valley, with a less well developed T1T3 terrace staircase developed onto steeply dipping Cretaceous bedrock (Fig. 6E). Mid and downstream TF areas comprise river gorge reaches cut into Jurassic and Palaeogene limestone lacking in river terraces (Fig. 4G).

Within the FB, terraces are again unclear due to the lithological similarities with the Plio-Quaternary basin infill. Slope morphological changes suggest fragmentary occurrences of T3. These terraces are inset into a top basin fill surface (Fig. 3B).

The bedrock geology strength (Table 1 ) shows a relationship to valley morphology (Figs. 3B and 4) and terrace occurrence (Fig. 5). High strength bedrock (Table 1) lacks terraces, forming narrow valleys with river gorge and canyon formation (Figs. 4A, C, D and 6C). Weak and Mixed-Weak bedrock are associated with wider valley forms and terrace occurrence, with well-developed T2-T4 levels along the lower valley sides but lacking higher-older levels. Mixed-Strong bedrock is often associated with the beginnings of narrower valley canyon development and the most well-developed terrace staircases (Figs. 5 and 7).

\section{River terrace sedimentology and stratigraphy}

River terraces are characterised by $1-3 \mathrm{~m}$ and rare $5-7 \mathrm{~m}$ thick

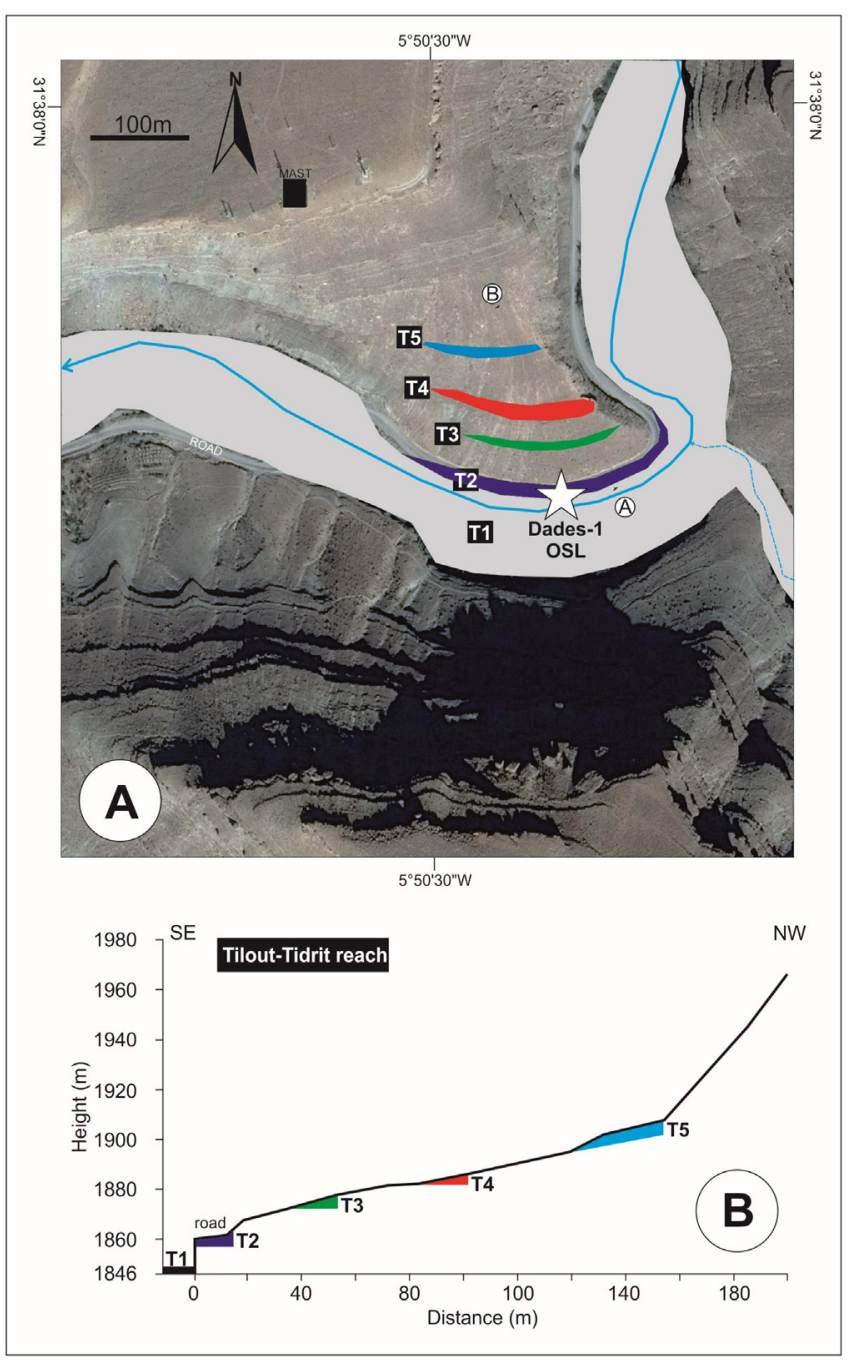

Fig. 7. Map (A) and topographic profile (B) of T1-T5 terrace staircase, upstream FTB region terrace staircase. See Fig. $8 \mathrm{E}$ and Supplementary Information for OSL sample information.

conglomerate units (Figs. 8 and 9). The conglomerates are coarse grained and dominated by boulder-cobble size clasts of Mesozoic limestone that are set within a poor-moderately sorted matrix of limestone pebbles, gravel and sand (Fig. 8A and B). The largest clasts are well rounded and often display clear imbrication (Fig. $8 \mathrm{~A}$ and $\mathrm{B}$ ). The conglomerates are either massive or display weak horizontal stratification, with rare occurrences of metre scale low angle cross-stratification (Fig. 8A,B, C,D). Terrace basal contacts are sharp, revealing an angular unconformity with underlying tilted Mesozoic/Cenozoic sediments (Fig. 8A). The bases display an undulating topography, whose scale is determined by the dip and lithological variability of the underlying bedrock. Post-depositional carbonate cementation of clasts is common, especially at the terrace bases (Fig. 8A). Terraces are rarely capped by fine to coarse sand units up to $\sim 2 \mathrm{~m}$ thick that are massive, lacking sedimentary structures (Figs. 8E and 9). Sand grains are dominated by carbonate compositions but do contain some quartz and feldspar.

The terrace conglomerates are interpreted to have been deposited by high energy fluvial processes based upon their coarse grain size and down valley imbrication. Horizontal and low angle cross-stratification suggests deposition as gravel sheets and 
longitudinal bar forms (lithofacies Gm, Gp: Miall, 1978) within a braided river system (e.g. Hein and Walker, 1977). The lack of fines and soil development within the conglomerates suggests high sediment mobility and reworking, as part of a sustained period of valley floor aggradation. Thickness variations in terrace bodies can be accounted for by either local accommodation space variability or by valley morphological differences between the valley sides and palaeo-axis/thalweg. Conglomerate carbonate cementation is typical of groundwater processes, with preferential cementation along terrace bases due to permeability differences between conglomerates and the bedrock (e.g. Nash and Smith, 2003). The overlying rare sands represent floodplain sedimentation or in overbank areas when flood waters overtop channel margins with deposition in slack water areas (e.g. Benito et al., 2003). Sedimentary structures are common in floodplain and slack water deposits (e.g. horizontal lamination or climbing ripples) but here their absence can be explained by insufficient grain size variability within the sediment laden flood waters. The quartz and feldspar content of the sands could be of aeolian Saharan dust origin but more simply is reworked from Middle-Upper Jurassic continental sedimentary bedrock found upstream of the study area.

Terrace conglomerates and rare sands are commonly overlain by up to $5 \mathrm{~m}$ of coarse grained gravels (Figs. 8F and 9). These are poorly sorted and weakly stratified, with angular clasts whose composition reflects the local bedrock geology. The gravels mantle the valley sides in relict degraded patches and rarer continuous aprons with sediment building out over the river terraces, possessing a slope apron morphology. When observed in proximity to tributary junctions the gravels have a fan-surface like morphology. Sediments are also associated with meander cut-offs, forming a slope infill of the abandoned valleys (Fig. 6F). These texturally immature gravels are interpreted as localised gravity driven slope deposits. At tributary junctions, the gravels relate to debris flows as relicts of tributary junction fans, similar to those observed in the modern Dadès River (Stokes and Mather, 2015; Mather et al., 2017). The terrace capping slope deposits are important for preserving the underlying fluvial sediments, acting as a valuable stratigraphic marker to assess the relative timings of river activity.

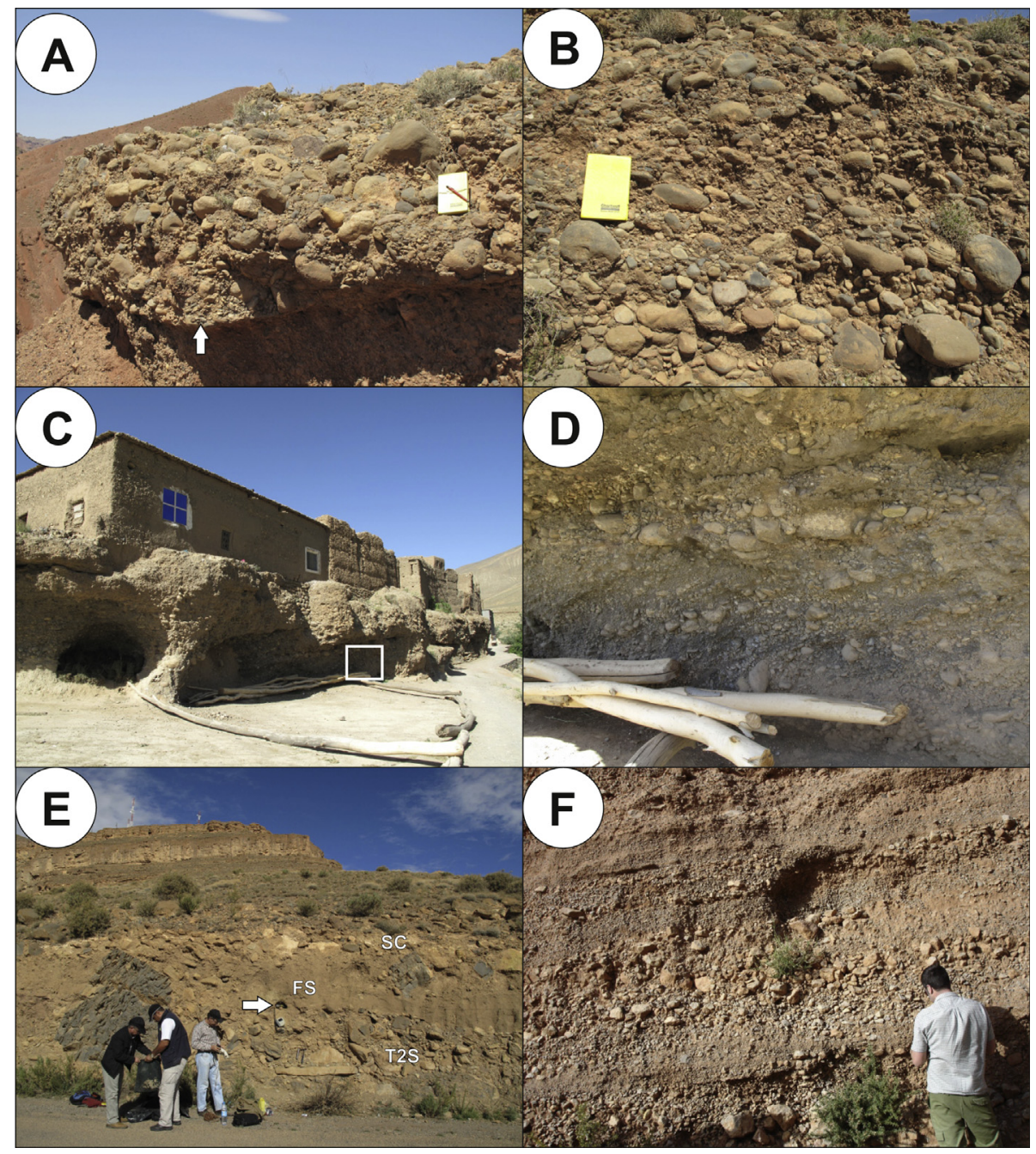

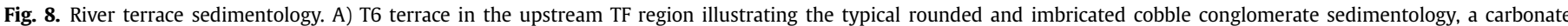

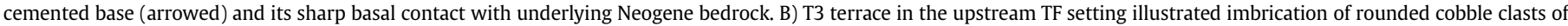

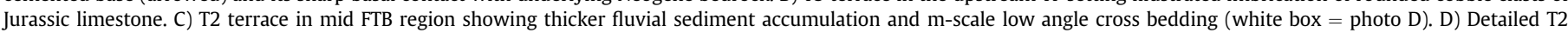

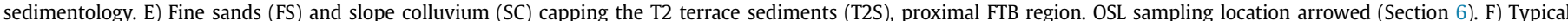

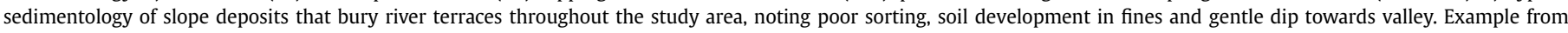
downstream T3 abandoned meander loop, mid FTB region (Fig. 5). 


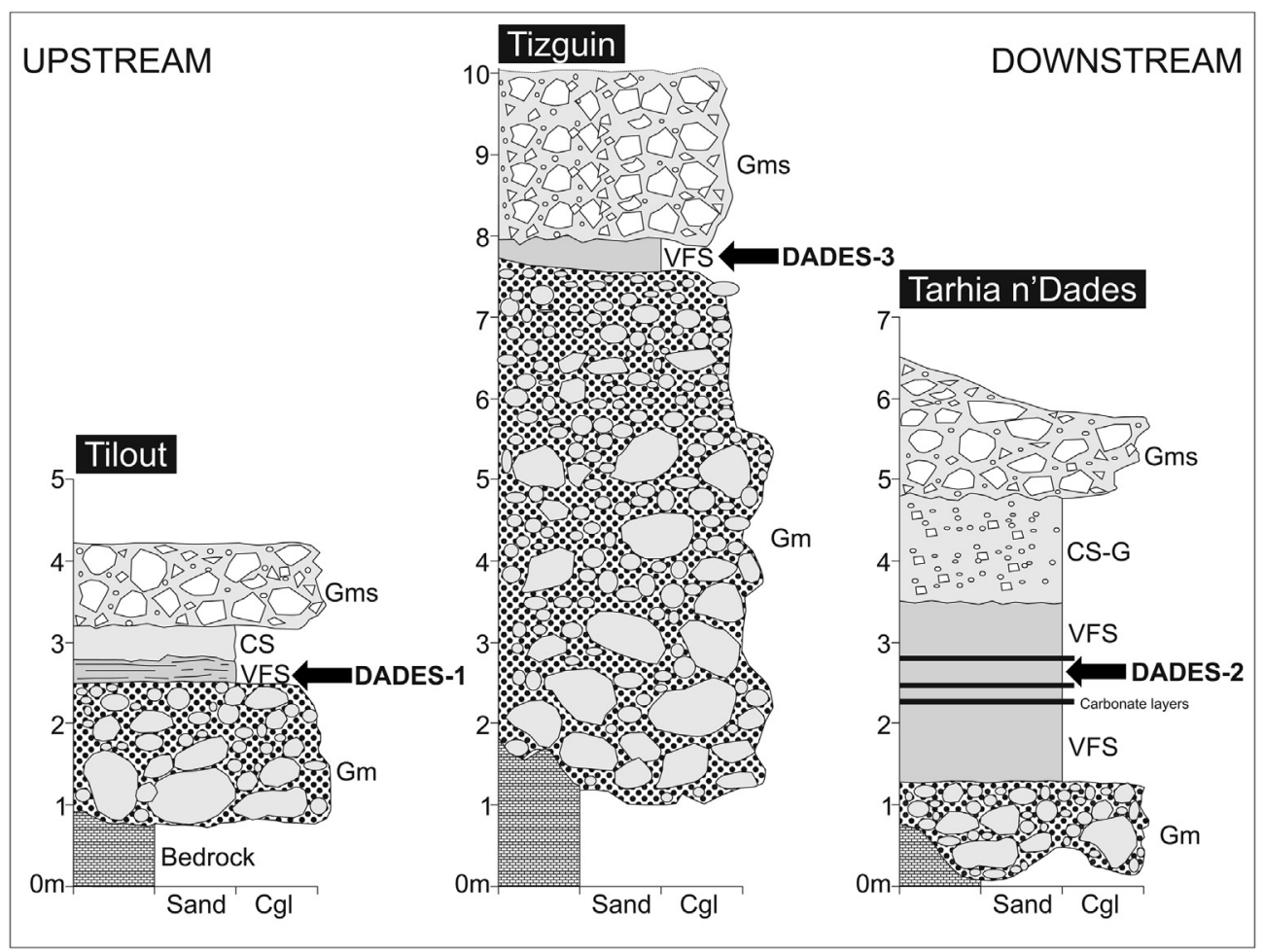

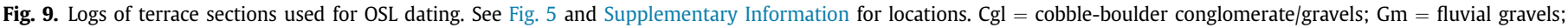
$\mathrm{Gms}=$ slope/tributary fan gravels; VFS = very fine sand; CS-G = coarse sand-gravel.

\section{OSL/IRSL dating}

Quartz and feldspar OSL/IRSL results are presented in Tables 2 and 3 with methods and a detailed technical discussion provided as Supplementary Information. The quartz age estimates (Dadès$1=69 \pm 7$ ka; Dadès $2=78 \pm 4$ ka; Dadès- $3=76 \pm 5 \mathrm{ka}$ ) show a mean age of 74 ka with a small 5 ka range (Table 2). Despite the age consistency between locations, older timescale quartz OSL ages (e.g. $>60-70 \mathrm{ka}$ ) are often considered to underestimate absolute ages (e.g. Buylaert et al., 2007) and are thus treated as minimum values. The feldspar age estimates (Dadès- $1=104 \pm 14 \mathrm{ka}$; Dadès $2=70 \pm 6 \mathrm{ka}$; Dadès- $3=102 \pm 8 \mathrm{ka}$ ) reveal a mean age of $92 \mathrm{ka}$ with a range of $9 \mathrm{ka}$ (Table 3). However, these estimates show some degree of variability when compared to each other and their

Table 2

Summary of equivalent dose values and calculated ages for quartz grains.

\begin{tabular}{lllll}
\hline Sample & Natural De \pm se $(\mathrm{Gy})$ & $\begin{array}{l}\text { Saturated }^{\mathrm{a}} \mathrm{De} \pm \mathrm{se} \\
(\mathrm{Gy})\end{array}$ & $\begin{array}{l}\text { Dose Rate } \\
(\mathrm{Gy} / \mathrm{ka})\end{array}$ & Age (Ka) \\
\hline Dades-1 & $190 \pm 17(\mathrm{n}=17)$ & $269 \pm 29(\mathrm{n}=16)$ & $2.76 \pm 0.1$ & $69 \pm 7$ \\
Dades-2 & $172 \pm 5(\mathrm{n}=27)$ & $327 \pm 21(\mathrm{n}=19)$ & $2.21 \pm 0.1$ & $78 \pm 4$ \\
Dades-3 & $195 \pm 6 .(\mathrm{n}=28)$ & $332 \pm 18(\mathrm{n}=20)$ & $2.55 \pm 0.1$ & $76 \pm 5$ \\
\hline
\end{tabular}

a Signal saturation equivalent at $2 \times$ Do (Wintle and Murray, 2006). equivalent quartz OSL ages (see Supplementary Information for discussion).

\section{Discussion}

\subsection{Geologic controls}

Modelling studies suggest that bedrock benches beneath strath terraces form when there is a change in ratio from vertical incision to lateral erosion (Hancock and Anderson, 2002). Within the study area, the potential for lateral bedrock erosion is greater in areas of weaker bedrock and restricted in stronger bedrock (Fig. 10). This is most notable in middle parts of the FTB (Fig. 5), where mixed-weak strength interbedded limestone-mudstone of the Lower Jurassic Ouchbis Formation (Fig. 4B) displays well-developed and laterally continuous T1, T2, T3 and T4 levels over some $20 \mathrm{~km}$ (Fig. 5). The structural configuration of this bedrock into a syncline, and the routing of the Dadès River down the syncline axis (Fig. 2) enhance further the potential for lateral erosion. Bedrock on both valley margins dips towards the valley axis due to the fold limb arrangement (see (2) on Fig. 3). This facilitates valley margin erosion through slope undercutting and shallow translational failures that exploit bedding plane dip and discontinuity configuration (Mather and Stokes, in press), a process reported in bedrock erosion field

Table 3

Summary of equivalent dose values and calculated ages for K-feldspar grains.

\begin{tabular}{|c|c|c|c|c|c|c|}
\hline Sample & $\begin{array}{l}\text { De }(G y) \\
\text { IR50 } \pm \text { se }\end{array}$ & $\begin{array}{l}\text { De }(G y) \\
\text { pIRIR290* } \pm \text { se }\end{array}$ & Ratio IR50: pIRIR290 & Dose Rate \pm se $(\mathrm{Gy} / \mathrm{ka})$ & Corrected* Age (Ka) pIRIR290 & Uncorrected Age (Ka) pIRIR290 \\
\hline Dades-1 & $139 \pm 24(n=8)$ & $371 \pm 58(n=5)$ & 1: 1.4 & $3.6 \pm 0.1$ & $104 \pm 17$ & $109 \pm 16$ \\
\hline Dades-2 & $114 \pm 8(n=9)$ & $212 \pm 10(n=9)$ & $1: 1.9$ & $3.0 \pm 0.1$ & $70 \pm 6$ & $77 \pm 5$ \\
\hline Dades-3 & $155 \pm 24(\mathrm{n}=16)$ & $343 \pm 28(n=16)$ & $1: 1.7$ & $3.4 \pm 0.1$ & $102 \pm 8$ & $108 \pm 7$ \\
\hline
\end{tabular}

${ }^{*}$ Corrected for residual dose significant at 24Gy. No ages are presented for IR50. See supplementary Information for discussion. 


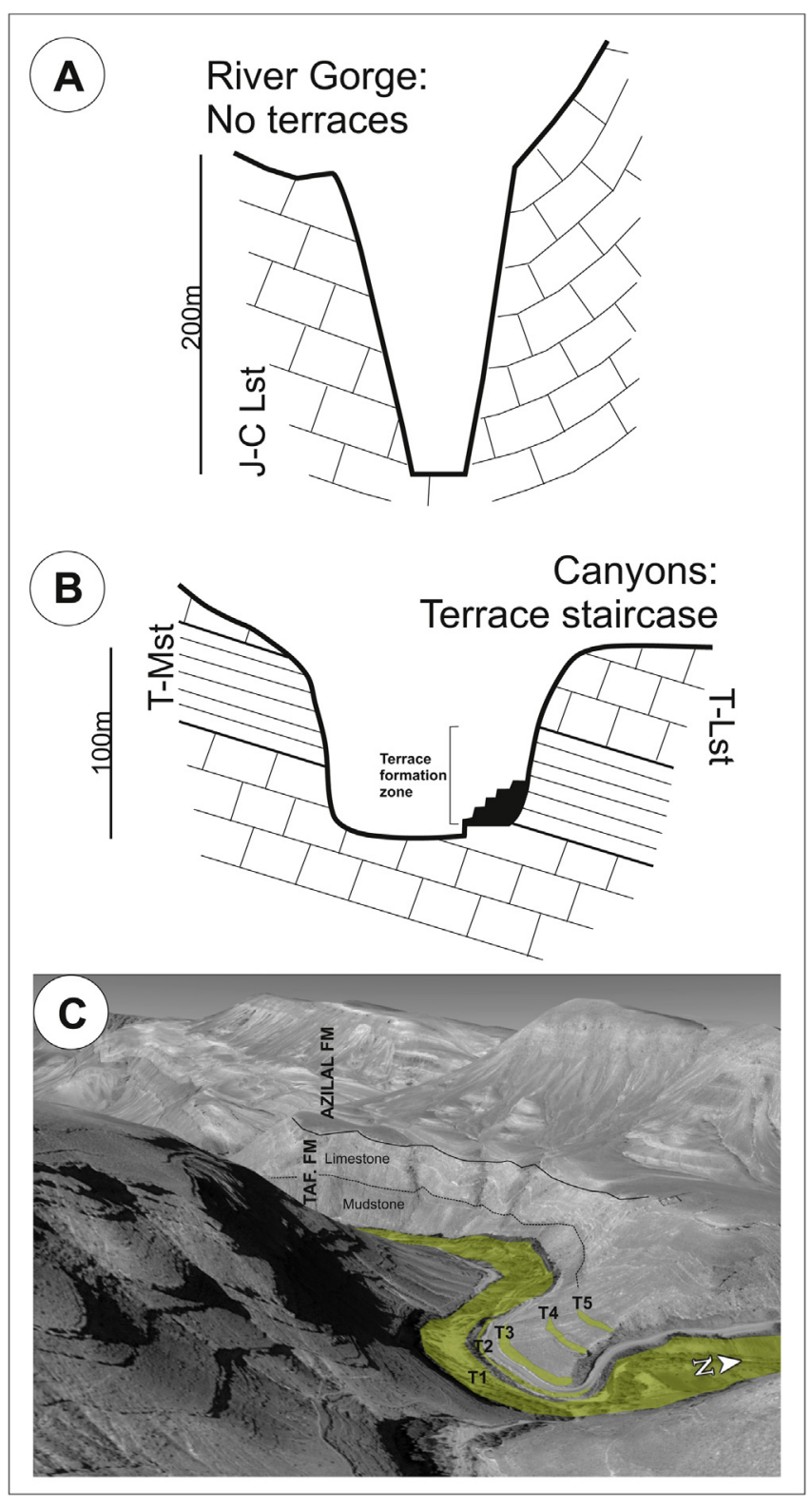

Fig. 10. A) River gorge reach of structurally thickened 'strong' limestone with no terrace formation. B) Confined canyon reach where river terrace staircase development is controlled by the strength variability in a dipping stratigraphic sequence of Tafraoute Fm mudstone (T-MSt) and limestone (T-Lst). C) Oblique Google Earth image illustrating rock strength, structure and stratigraphic sequence relationships to terrace staircase formation at the Tilout site (Fig. 7).

and modelling studies (e.g. Weissel and Seidl, 1997).

Fluvial bedrock erosion occurs through combinations of solution, plucking, cavitation and abrasion depending upon substrate lithology and discontinuities (Whipple et al., 2000). Within the study area, the dominance of Mesozoic carbonate substrate suggests some degree of solution (e.g. de Jong et al., 2008). However, field evidence from bedrock reaches (Stokes et al., 2008) and the basal contacts of terraces (Section 5) suggest erosion is dominated by plucking/cavitation and abrasion. Terrace sediments are almost entirely composed of cobble size clasts of Lower-Middle Jurassic limestone (Section 5) with little mudstone clast material. Similar grain size and composition characteristics occur within the active thin alluvial covers in the modern Dadès River bedrock reaches. Limestone bedrock readily breaks down into decimetre blocks due to joint configuration (Stokes et al., 2008). The massive crystalline properties of the limestone provide high rock strength, acting as an abrasion tool when transported as bedload over weaker mudstone bedrock. In terms of strath terrace formation, the bedrock bench corresponds to a period where bedload and discharge are sufficient to abrade and widen the valley floor but sediment supply is insufficient to cause valley floor aggradation (Hancock and Anderson, 2002; Montgomery, 2004).

Terrace staircases record longer term patterns of fluvial downcutting, with multiple ratio changes from vertical incision to lateral erosion. Studies routinely attribute terrace staircase formation to sustained base-level lowering driven by combinations of tectonic and/or climatic changes (e.g. Starkel, 2003; Bridgland and Westaway, 2008a,b). Within the study area, terrace staircases comprising $>4$ levels occur in localised parts of the FTB and TF settings (Fig. 5). These staircases occupy locations of pronounced deviation in river valley direction, developing on valley margin spurs where the river has progressively migrated and incised (Figs. 7 and 10B, C). Whilst base-level lowering has undoubtedly influenced the terrace staircase development, rock strength has played an equally important role. Staircases have developed in areas of weaker rock strength (e.g. TF staircase $=$ Neogene mudstones and sandstones) that are conducive to both vertical and lateral erosion. The FTB staircase (Figs. 5, 7 and 10B, C) is particularly notable for being the most complete in terms of the number of levels $(\times 5$ : T1-T5) and showing a clear relationship to substrate strength. Here, the Dadès valley cuts through the Tafraout Formation (Table 1), a Lower-Middle Jurassic sequence of limestone and mudstone (Carte Géologique du Maroc, 1993). The terrace staircase has locally exploited a mudstone part of the sequence along the lower and middle valley sides, whilst a return to decimetre thick limestone in upper valley side positions has suppressed terrace formation at higher landscape levels (Fig. 10B and C). Downstream, in middle reaches of the FTB, terrace staircases may have developed but have been eroded due to being subjected to longer timescales of valley side erosion into the underlying homogeneously weak bedrock (e.g. Ouchbis Fm). Thus, the collective strength of the underlying bedrock geology and its stratigraphic and structural configuration can either enhance or suppress terrace formation or contribute significantly to poor terrace preservation (Fig. 10), similarly observed for river gorge development in the area (Stokes et al., 2008).

\subsection{Climate controls}

In this study, the typical terrace stratigraphic configuration, irrespective of landform level, is a bedrock bench, overlain by coarse fluvial conglomerates with rare caps of overbank sands that are collectively buried by slope/tributary fan sediments (Fig. 11). This sequence can be explained by climate-related behaviours of the river channel and its adjacent hillslopes (Fig. 11). The fluvial conglomerates correspond to the aggradation phase (Fig. 11), when there is elevated coarse-grained sediment supply to the valley floor from the hillslopes, tributaries and upstream catchment areas due to effective slope-channel coupling (sensu Harvey, 2002) and sufficient discharge to mobilise coarse sediment (e.g. Bull, 1991). The overlying overbank sands can be explained in two ways: 1) as continued valley floor aggradation, but the final stages immediately prior to the onset of incision, where coarse-grained sediment supply is limited, or 2) in relation to valley floor incision (Fig. 11) when the river channels have a reduced sediment supply, but where floodwaters can still overtop incised terrace surface (e.g. Wang et al., 2014). The latter is the simpler (and preferred) explanation being commonly observed in the modern Dadès River flood hydrology where flood waters overtop the valley floor T1 terrace 


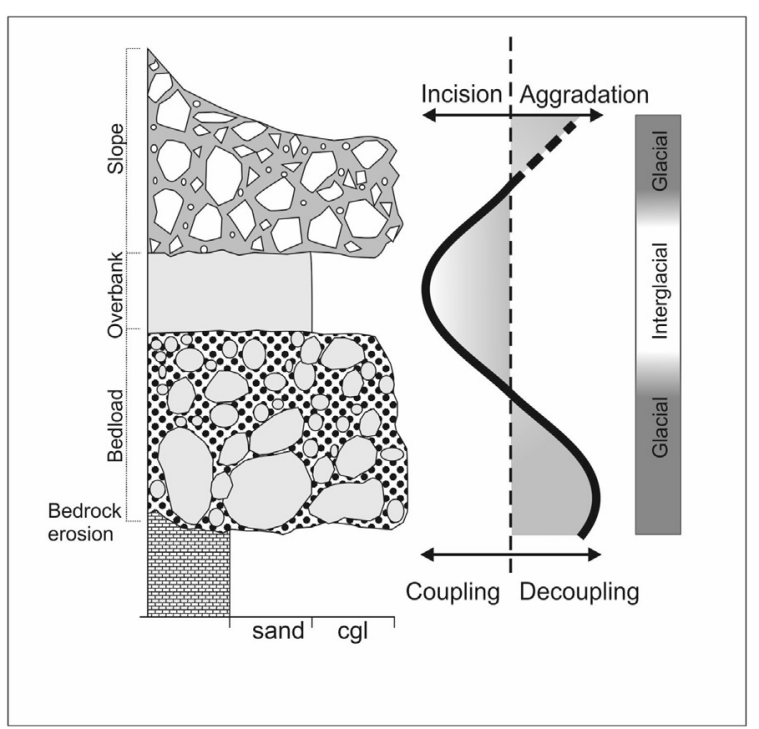

Fig. 11. A conceptual river terrace-climate model for the Dadès River illustrating the relationship between glacial-interglacial climates, valley floor incision-aggradation patterns and river channel-hillside coupling status.

depositing sand and silt. The terrace capping slope/fan deposits suggest valley floor incision (Fig. 11) with hillslope material burying the valley side terrace remnants but with insufficient river flood discharge to activate meaningful valley floor aggradation, a decoupling of the channel and hillslopes (Mather et al., 2017). The bedrock bench is cut early in the transition between the incision and aggradation phases (Fig. 11), a threshold period when flood regime and sediment supply is increasing to a sufficient level for bedload transport (tools) to cause lateral erosion into valley sides (Hancock and Anderson, 2002; Montgomery, 2004).

OSL/IRSL dating of the T2 overbank sands, although limited in number, provides some insight into terrace incision timing (Fig. 11). Whilst quartz OSL ages were considered as minimum ages only (Table 2; Supplementary Information), the corrected feldspar ages (Table 3) of $104 \pm 17 \mathrm{ka}$ (upstream), $70 \pm 6 \mathrm{ka}$ (downstream) and $102 \pm 8 \mathrm{ka}$ (mid-reach) were considered more representative. These ages, including error bars, span the Marine Isotope Stage (MIS) 5 interglacial and MIS 4 glacial climate periods. River terrace research (e.g. Vandenberghe, 2015 and references therein) states that incision normally takes place during the climate transitions. This study agrees, with T2 incision most likely to have taken place during the MIS 6/5 cold-warm transition. By stratigraphic bracketing, this means that aggradation of the T2 fluvial gravels probably took place during the MIS 6 glacial and that slope colluvium was deposited over the T2 gravels and rare overbank sands during the MIS 4-2 glacial. The T2 stratigraphic configuration and timing has some affinities to sequences described by Weisrock et al. (2006) and Mercier et al. (2009) from the coastal region of the Anti-Atlas Mountains (Fig. 1). Using OSL, U-Series and radiocarbon dating, they proposed a major pre-MIS 5 fluvial incision and basal fluvial gravel aggradation phase, followed by MIS 5-3 fluvial-slope travertine-silt-sand aggradation and capped by a MIS 2 aeolian-slope silt deposit. Furthermore, studies of western Mediterranean dated terrace records (e.g. Macklin et al., 2002; Santisteban and Schulte, 2007) suggest a complex pattern of fluvial aggradation and incision phases during the Middle-Late Pleistocene. Of note are reports of regionally synchronous MIS 6 aggradation and MIS 5 incision phases in southern Spain and NE Libya (Macklin et al., 2002). Thus, it seems that on the south side the High Atlas along the NW Saharan margin, the MIS 6 fluvial aggradation and onset of incision at the
MIS 6/5 transition have some degree of harmony with the Western Mediterranean region, acknowledging the restricted dataset in terms of sites and age control. Dated fluvial sequences are starting to emerge from northern Morocco in relation to early human occupation research, describing fluvial aggradation in MIS 6/5e (e.g. Bartz et al., 2015). However, these are localised site specific archaeologically focussed studies where the fluvial geomorphological context is insufficient to make meaningful comparisons to river terrace records.

If a similar climate relationship is considered for $\mathrm{T} 1$ that currently occupies large parts of the wider valley floor settings, this means that the coarse grained fluvial sediment corresponds to the Late Pleistocene glacial (MIS 2), whilst the onset and ongoing (small) incision phase is Late-Pleistocene-Holocene (MIS 2/1). Sands cap the T1 terrace fluvial gravels and these are similar to the rare occurrences of the OSL/IRSL dated T2 sands. Interestingly, slope colluvium is not yet building out over the T1 terrace, with terrace top sedimentation limited to localised tributary junction fan occurrences (Stokes and Mather, 2015). Much of the valley sides are bedrock, with only patches of colluvial veneer remaining. This suggests hillslope sediment is almost exhausted and decoupled from the river channel (Fig. 11) with another phase of cold-climate (peri)glacial weathering required to regenerate sufficient hillslope material to start to bury the T1 terrace (Mather et al., 2017). Although glacial periods are dominated by aridity in NW Africa as illustrated by Saharan dune activity (Fig. 1; e.g. Lancaster et al., 2002), high altitude lake records (e.g. Lake Isli [Fig. 1.], $50 \mathrm{~km}$ north of the Dadès: Lamb et al., 1994; Valero-Garcés et al., 1998) show complex and detailed patterns of cold climate aridityhumidity variability which helps clarify the timing of the T1 terrace formation. The lake record shows a marked change from elevated aridity, low lake levels ( $>35-28 \mathrm{ka}$ ) and erosion (28-20 ka) during the Full Glacial, changing to sustained humidity and high lake levels (20-11 ka) during the late Glacial Transition (Valero-Garcés et al., 1998). Lake Isli is positioned on the Dadès River drainage divide and thus the downstream valley effects are probably slope colluvium activity supplying excess sediment to the valley floor resulting in aggradation during the cold-arid Full Glacial (pre-20 ka), followed by slope erosion and valley floor incision during the late Glacial Transition period (post-20 ka) when the climate ameliorates becoming more humid (e.g. Gibbard and Lewin, 2002). Furthermore, although the Dadès catchment was not glaciated, the development of small ice fields and valley glacier advance in the Toubkal region (Fig. 1) at 76, 24 and $12 \mathrm{ka}$ (Hughes et al., 2011) further illustrates the cold climate conditioning of the High Atlas landscape. In the Dadès catchment, periglacial activity would have been important for slope weathering and sediment supply to the valley floor but clear periglacial evidence are lacking from the terrace sediments (e.g. cryoturbations etc). The 24 ka Toubkal advance approximates to the proposed T1 aggradation period, but the relationship of the $76 \mathrm{ka}$ and $12 \mathrm{ka}$ events to the terrace record remains unclear.

If the main periods of valley floor fluvial aggradation took place in the glacial periods (i.e. MIS 2 and 6) and major incision during warming transitions (i.e. $6 / 5$ and $2 / 1$ ), this suggests that fluvial landscape dynamics in the south-central High Atlas are tuned to 100 ka Milankovitch cycles, showing affinity to other terraceclimate studies from around the world (e.g. Bridgland and Westaway, 2008a; Vandenberghe, 2015). If this Milankovitch relationship is developed further, and that each of the well-developed, laterally continuous terrace level (T1-T4) relates to a full climate cycle, it means that the Dadès River records some $400 \mathrm{ka}$ of fluviallandscape dynamics spanning the Middle-Late Pleistocene (Fig. 12). It also suggests that rare terraces higher than T6, i.e. $>50 \mathrm{~m}$ above the modern river, are Early Pleistocene in nature (Fig. 12) and they 


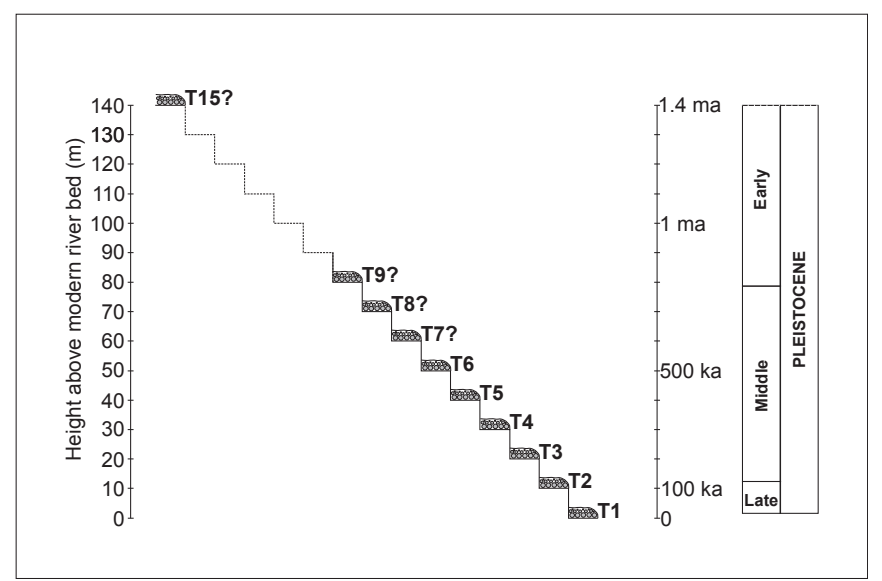

Fig. 12. Pleistocene temporal pattern of the Dadès River terrace sequence.

offer a significant potential for linking orogenic basin sedimentary records (e.g. WTB, FB) to incision of the FTB region.

High Atlas drainages, including the Dadès River, are routed downstream into the Ouarzazate Basin. Here, remnants of large alluvial fans are recorded in west-central basin areas, with studies documenting up to 5 inset fan surfaces (Stäblein, 1988; Littmann and Schmidt, 1989; Sébrier et al., 2006). This number of surface levels has some broad stratigraphic agreement with the upstream Dadès River terraces (e.g. T1-T5). Furthermore, there is some degree of temporal agreement from cosmogenic exposure dating of the fan surfaces by Arboleya et al. (2008). They suggest that fan surface abandonment and incision is climatically controlled, occurring broadly over a series of 100 ka cycles during the Holocene (MIS 1) and Middle-Late Pleistocene (MIS 5, 7, 9). Delcaillau et al. (2016) have described fan-terrace sequences from the Ourika valley on the north (Marrakech) side of the High Atlas. They consider climate as a key control on the incision and aggradation patterns but their study lacks age control, and thus clear climate relationships are lacking.

This broad pattern of $100 \mathrm{ka}$ cycles is illustrated in regional scale Quaternary climate modelling studies for NW Africa, where marked spatial and temporal patterns of changes in precipitation are recorded (Tjallingii et al., 2008). For the Sahara, aridity dominates but precipitation becomes elevated during the climate transitions: 1) interglacial-glacial (e.g. MIS 5-4) and 2) glacial-interglacial (MIS 2-1) (Tjallingii et al., 2008), coinciding with the proposed periods of incision in the Dadès River.

\subsection{Base-level lowering controls}

Whilst climate ultimately controls variations in sediment-water supply leading to changes in valley floor aggradation and incision (Bull, 1991), sustained base-level lowering is required to form an inset sequence of river terrace levels (Vandenberghe and Maddy, 2001; Bridgland and Westaway, 2008a). If the rate of base-level lowering is small then complex fill terraces develop (Lewin and Gibbard, 2010), contrasting with high rates of base-level fall which leads to strath terrace and staircase formation (Starkel, 2003). Base-level lowering can be controlled by combinations of climate, river capture and tectonics.

Climate-related base-level lowering is normally attributed to eustacy, typically affecting downstream, coastal regions of river systems where falling sea level causes incision, whereas rising sea level causes aggradation (e.g. Stokes et al., 2012a and references therein). The continental situation of the Dadès River ( $900 \mathrm{~km}$ from modern sea level) means that eustatic base-level lowering affects are negligible.

River capture involves drainage rerouting and catchment area expansion and loss respectively of the capturing and captured system (e.g. Stokes et al., 2002). The enlarged capturing system is at a lower base-level and once capture occurs, the base-level difference is transmitted upstream through the captured catchment (Mather et al., 2002). The Ouarzazate Basin has been captured by the Draa River in the Quaternary, whereby the internally drained Ouarzazate Basin was captured and re-routed southwards across the Anti-Atlas through the Draa Gorge (Stäblein, 1988; Arboleya et al., 2008). Capture-related impacts upon the drainage network are unclear due data collection absence. However, capture-related incision should account for some fluvial erosion in lower drainage system parts of the Ouarzazate Basin. Whether capture-related incision has transmitted upstream across the SAF and upstream into the High Atlas FTB region is unclear but unlikely (Boulton et al., 2014).

Tectonic uplift is a commonly cited mechanism for long term base-level lowering in river terrace studies (e.g. Lavé and Avouac, 2001; Cunha et al., 2008), with fill terraces forming under low uplift rate conditions and strath terraces forming under intermediate and higher uplift rate scenarios (Starkel, 2003).

The High Atlas topography has been generated during the Cenozoic linked to ongoing Africa-Europe collision. Despite debate, relief appears to have been generated during the Eocene-Oligocene and Plio-Quaternary (Frizon de Lamotte et al., 2000), through combined mechanical shortening (folding/thrusting) and mantlerelated isostatic processes (e.g. Teixell et al., 2003; Missenard et al., 2006). The Dadès terrace record corresponds to the PlioQuaternary uplift stage, recording the most recent phase of longer term drainage evolution. The uplift has generated a regional NNW-SSE topographic gradient but the Dadès River is routed obliquely SW across this gradient exploiting the axes of $\mathrm{km}$-scale fold structures within the Jurassic bedrock of the FTB region (Figs. 2 and 4). Fig. 5 reveals a marked parallel configuration of the $\mathrm{T} 1$ to T4 terrace levels as they pass through all tectonic components of the High Atlas orogen. This includes the TF region where elevated rates of active tectonic uplift could be expected. Field mapping and cross-section compilation by Tesón and Teixell (2008) demonstrates extensive folding and faulting in the TF region but this is restricted to Jurassic to Plio-Quaternary bedrock. Our terrace mapping did reveal minor m-scale thrust faulting of terrace sediments but this was exceptionally rare, affecting the T3 level (Fig. 13). Faulting exploited bedding planes of tilted Neogene bedrock, with propagation up into the terrace sediments towards the NW (Fig. 13). Fault planes were low angle $\left(\sim 30^{\circ}\right)$, with small $(<2 \mathrm{~m})$ vertical and horizontal offsets (Fig. 13). This lack of terrace deformation, even in TF areas where it would be expected, suggests that the High Atlas in the Dadès River region was characterised by low rate tectonic activity, at least from the Middle-Late Pleistocene onwards. This is further supported by low modern seismic activity, where earthquakes, concentrated along the SAF region, are infrequent and low magnitude (magnitude <4.9) (Medina and Cherkaoui, 1991). However, there is uncertainty as to how deformation at the surface relates to the deformation at depth which generates earthquakes (Sébrier et al., 2006). Quaternary fan surfaces south of the SAF in the Ouarzazate Basin do display a greater degree of surface faulting and folding (Sébrier et al., 2006; Arboleya et al., 2008) but these are spatially variable along different fault segments of the SAF mountain front. However, this surface deformation requires improved age control to confirm deformation timing and its relationship to basin and mountain front incision.

River terraces with age control can be used to quantify fluvial incision rates which in turn can be developed further to inform on 


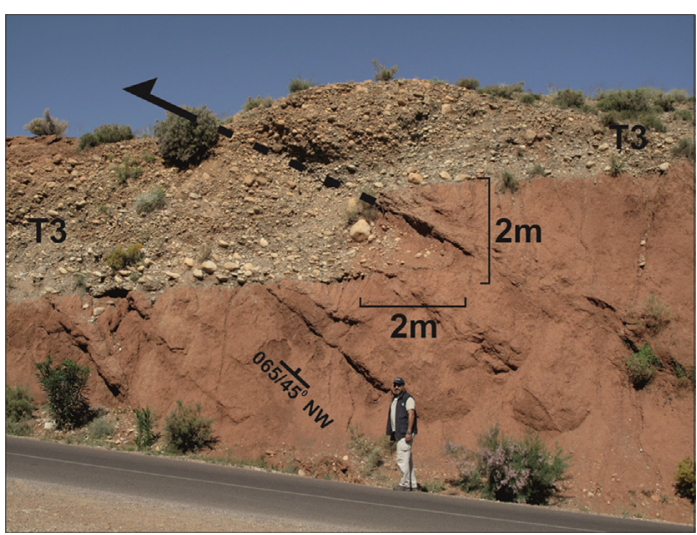

Fig. 13. T3 terrace deformation in the Thrust Front region $\left(31^{\circ} 26^{\prime} 58.92 \mathrm{~N}\right.$ $5^{\circ} 58^{\prime} 12.63 \mathrm{~W}$ ), illustrating thrust faulting (dip $=30^{\circ}$; apparent strike $=065$ ) of fluvial terrace gravels. Faulting is exploiting bedding plane dip of tilted Neogene bedrock (45/ $065 \mathrm{NW})$.

spatial and temporal patterns of uplift (e.g. Lavé and Avouc, 2001). In this study, the OSL dated fluvial overbank sands of the T2 terrace provide some opportunity for quantifying incision. The Dadès-1 $(104 \pm 17 \mathrm{ka})$ and Dadès-3 $(102 \pm 8 \mathrm{ka})$ samples were taken from sands immediately overlying coarse fluvial gravels at heights of $12.5 \mathrm{~m}$ and $17.75 \mathrm{~m}$ above the modern river level (Fig. 10), producing respective incision rate estimates and error ranges of 0.12 $(0.10-0.14) \mathrm{mm} \mathrm{a}^{-1}$ to $0.17(0.16-0.19) \mathrm{mm} \mathrm{a}^{-1}$. Higher rates of $0.3-1.0 \mathrm{~mm} \mathrm{a}^{-1}$ were reported by Arboleya et al. (2008) from incised Quaternary fans in the Ouarzazate Basin, possibly reflecting 1 ) proximity to the Dadès-Draa capture site, 2) positioning along a more active SAF thrust segment or 3 ) rock strength differences between different components of the orogen.

Compared to other studies that report incision rate from river terraces in a collisional mountain tectonic context (e.g. Lavé and Avouac, 2001; Cunha et al., 2008) the rates reported here are low, suggesting the south-central High Atlas has evolved under low rock uplift rate conditions since the Late Pleistocene. Furthermore, the systematic altitudinal spacing of the T1-T4 terraces throughout the $60-\mathrm{km}$-long study area suggests that similarly low incision rates $\left(<0.2 \mathrm{~mm} \mathrm{a}^{-1}\right)$ have been maintained throughout the Quaternary, at least from the Middle Pleistocene onwards. The consistency in spatial and temporal distribution of the river terraces implies that the Dadès River is responding to some kind of regional tectonically driven, low rate base-level lowering process. Rather than fault/fold related mechanical uplift, the base-level lowering could be linked to isostatic uplift related to mantle upwelling under the High Atlas that has been widely associated with longer term geophysicalseismic studies of High Atlas topographic development (e.g. Missenard et al., 2006) and from regional quantitative tectonic geomorphological studies of drainage networks along the north and south of the central High Atlas (Delcaillau et al., 2010; Boulton et al., 2014).

\section{Conclusions}

Collectively, this study highlights the significant opportunity that river terrace sequences hold for providing insights into Quaternary fluvial landscape development in NW Africa along the Saharan Desert margins. The study shows:

1. river terraces are widespread, yet little studied landforms throughout the High Atlas and the broader NW African desert mountain landscapes, a notable research gap of significant relevance for the geological, geomorphological and Quaternary science communities;

2. terrace formation in the High Atlas, and more generally within collisional mountain belts, can be strongly influenced by rock strength and its relationship to the structural and stratigraphic configuration of the orogen;

3. dating of river terraces within dryland mountain landscapes in NW Africa is possible despite the rareness of fluvial sands with appropriate mineral compositions suitable for dating longer time series (e.g. OSL);

4. with some age control, terrace formation can be linked to climate-related incision and aggradational behaviour of the river channel and valley side slopes, operating over $100 \mathrm{ka}$ climate cycles. For a given cycle, incision occurs during the coldwarm transitions and aggradation during the full glacial. This is a pattern recorded elsewhere along the NW Saharan margin in the area south of the High Atlas, and appears synchronous with western/southern Mediterranean fluvial archives;

5. the terrace sequence suggests that fluvial landscape development spans the Late-Middle Pleistocene and possibly into the Early Pleistocene. This provides a significant future opportunity for a) understanding the Cenozoic development of the High Atlas Mountain topography through linkage and integration of geological and geomorphological records; and b) understanding spatial and temporal patterns of low latitude Quaternary climate change through integration with other limited regional climate archives (e.g. glaciers, lakes, dunes etc.) from the NW Saharan margin;

6. the spatial and temporal uniformity of terrace occurrence suggests a very low regional incision rate across all components of the High Atlas orogen (i.e. FTB, WTB, TF and FB);

7. the low regional incision rate coupled with a general absence of terrace tectonic deformation suggests that base level lowering is probably driven by mantle-related rock uplift rather than mechanical fold and thrust related crustal shortening. This further implies that High Atlas relief generation is an Early Pleistocene or older phenomenon.

\section{Acknowledgements}

Funding: This work was supported by a National Geographic research grant (8609-09). Jamie Quinn is thanked for drafting Fig. 2. We thank Profs. David Bridgland and Jef Vandenberghe for their positive and thought provoking reviews and QSR Editor Prof Yang for editorial handling.

\section{Appendix A. Supplementary data}

Supplementary data related to this article can be found at http:// dx.doi.org/10.1016/j.quascirev.2017.04.017.

\section{References}

Adamiec, G., Aïtken, M.J., 1998. Dose-rate conversion factors: update. Anc. TL 16, $37-50$.

Arboleya, M.-L., Babault, J., Owen, L.A., Teixell, A., Finkel, R.C., 2008. Timing and nature of Quaternary fluvial incision in the Ouarzazate foreland basin, Morocco. J. Geol. Soc. Lond. 165, 1059-1073.

Babault, J., Van Den Driessche, J., Teixell, A., 2012. Longitudinal to transverse drainage network evolution in the High Atlas (Morocco): the role of tectonics. Tectonics 31, TC4020.

Bartz, M., Klasen, N., Zander, A., Brill, D., Rixhon, G., Seeliger, M., Eiwanger, J., Weniger, G.-C., Mikdad, A., Brückner, H., 2015. Luminescence dating of ephemeral stream deposits around the Palaeolithic site of Ifri n'Ammar (Morocco). Quat. Geochronol. 30, 460-465.

Benito, G., Sánchez-Moya, Y., Sopeña, A., 2003. Sedimentology of high-stage flood deposits of the Tagus River, Central Spain. Sediment. Geol. 157, 107-132.

Boulton, S.J., Stokes, M., Mather, A.E., 2014. Transient fluvial incision as an indicator 
of active faulting and Plio-Quaternary uplift of the Moroccan High Atlas. Tectonophysics $633,16-33$.

Bridgland, D.R., Westaway, R., 2008a. Climatically controlled river terrace staircases: a worldwide Quaternary phenomenon. Geomorphology 98, 285-315.

Bridgland, D.R., Westaway, R., 2008b. Preservation patterns of Late Cenozoic fluvial deposits and their implications: results from IGCP 449. Quat. Int. 189, 5-38.

Bridgland, D.R., Westaway, R., 2014. Quaternary fluvial archives and landscape evolution: a global synthesis. Proc. Geol. Assoc. 125, 600-629.

Bull, W.B., 1991. Geomorphic Responses to Climatic Change. Oxford Univ. Press, Oxford, p. 326.

Buylaert, J.P., Vandenberghe, D., Murray, A.S., Huot, S., De Corte, F., Van den Haute, P., 2007. Luminescence dating of old ( $70 \mathrm{ka})$ Chinese loess: a comparison of single-aliquot OSL and IRSL techniques. Quat. Geochronol. 2, 9-14.

Buylaert, J.P., Jain, M., Murray, A.S., Thomsen, K.J., Thiel, C., Sohbati, R., 2012. A robust feldspar luminescence dating method for Middle and Late Pleistocene sediments. Boreas 41, 435-451.

Carte Géologique du Maroc, 1975. Jbel Saghro-Dadès. 1:200,000.

Carte Géologique du Maroc, 1985. Morocco map 1:1000,000. Notes and Memoir, No. 260.

Carte Géologique du Maroc, 1990. Zawyat Ahançal. 1:100,000.

Carte Géologique du Maroc, 1993. Tinerhir. 1:100,000.

Cavini, L., 2012. Alluvial Deposits in Aït Seddrat Basin and Dadès River Valley in the Framework of the Evolution of the Southern Front of the Central High Atlas, Morocco. MSc Thesis. University of Florence, p. 27.

Chellai, E.H., Perriaux, J., 1996. Evolution geodynamique d'un bassin d'avant-pays du domaine atlasique (Maroc): exemple des depots neogenes et quaternaires du versant septentrional de l'Atlas de Marrakech. Comptes Rendus 322, 727-734 (Serie II).

Cunha, P.P., Martins, A.A., Huot, S., Murray, A., Raposo, L., 2008. Dating the Tejo river lower terraces in the Ródão area (Portugal) to assess the role of tectonics and uplift. Geomorphology 64, 271-298.

Delcaillau, B., Laville, E., Amhrar, M., Namous, M., Dugué, O., Pedoja, K., 2010. Quaternary evolution of the marrakech high atlas and morphotectonic evidence of activity along the Tizi N'Test fault, Morocco. Geomorphology 118, 262-279.

Delcaillau, B., Dugué, O., Namous, M., Pedoja, K., Amhrar, M., Laville, E., 2016. Pleistocene fluviatile deposits in the Ourika drainage basin (Marrakech High Atlas, Morocco): indicators of climatic variations associated with base level change. Z. Geomorphol. 60, 1-20.

DeCelles, P.G., Giles, K.A., 1996. Foreland basin systems. Basin Res. 8, 105-123.

de Jong, C., Cappy, S., Finckh, M., Funk, D., 2008. A transdisciplinary analysis ofwater problems in the mountainous karst areas of Morocco. Eng. Geol. 99, 228-238.

Dewey, J.F., Helman, M.I., Turco, E., Hutton, D.H.W., Knott, S.D., 1989. Kinematics of the western mediterranean. In: Coward, M.P., Dietrech, D., Park, R.G. (Eds.), Alpine Tectonics, vol. 45. Geological Society, London Special Publication, pp. 265-283.

Dłużewski, M., Krzemień, K., Rojan, E., Biejat, K., 2013. Stream channel development in the southern parts of the High Atlas Mountains, Morocco. Geografija 49, $10-21$.

Duller, G.A.T., 2003. Distinguishing quartz and feldspar in single grain luminescence measurements. Radiat. Meas. 37, 161-165.

El Harfi, A., Lang, J., Salomon, J., Chellai, E.H., 2001. Cenozoic sedimentary dynamics of the Ouarzazate foreland basin (central high atlas mountains, Morocco). Int. J. Earth Sci. 90, 393-411.

Fink, A.H., Knippertz, P., 2003. An extreme precipitation event in Southern Morocco in Spring 2002 and some hydrological implications. Weather 58, 377-387.

Frizon de Lamotte, D., Saint Bezar, B., Bracène, R., Mercier, E., 2000. The two main steps of the Atlas building and geodynamics of the western Mediterranean. Tectonics 19, 740-761.

Frizon de Lamotte, D., Zizi, M., Missenard, Y., Hafid, M., El Azzouzi, M., Maury, R.C., Charrière, A., Taki, Z., Benammi, M., Michard, A., 2008. The atlas system. In: Michard, A., Saddiqi, O., Chalouan, A., Frizon de Lamotte, D. (Eds.), Continental Evolution: the Geology of Morocco. Structure, Stratigraphy and Tectonics of the Africa-Atlantic-mediterranean Triple Junction, vol. 116. Lecture Notes in Earth Sciences, pp. 133-202.

Gibbard, P.L., Lewin, J., 2002. Climate and related controls on interglacial fluvial sedimentation in lowland Britain. Sediment. Geol. 151, 187-210.

Gomez, F., Beauchamp, W., Barazangi, M., 2000. Role of the atlas mountains (northwest Africa) within the African-Eurasian plate-boundary zone. Geology 28, 775-778.

Görler, K., Helmdach, F.F., Gaemers, P., Heissig, K., Hinsch, W., Mädler, K., Shwarzhans, W., Zucht, M., 1988. The uplift of the central High Atlas as deduced from Neogene continental sediments of the Ouarzazate province, Morocco. Lect. Notes Earth Sci. 15, 363-404.

Goudie, A.S., 2006. The Schmidt Hammer in geomorphological research. Prog. Phys. Geogr. 30, 703-718.

Hancock, G.S., Anderson, R.S., 2002. Numerical modeling of fluvial strath-terrace formation in response to oscillating climate. Geol. Soc. Am. Bull. 114, 1131-1142.

Harvey, A.M., 2002. Effective timescales of coupling within fluvial systems. Geomorphology 44, 175-201.

Hein, F.J., Walker, R.G., 1977. Bar evolution and development of stratification in the gravelly, braided, kicking Horse river, British Columbia. Can. J. Earth Sci. 14, $562-570$.

Hughes, P.D., Fenton, C.R., Gibbard, P.L., 2011. Quaternary glaciation in the atlas mountains of North Africa. In: Ehlers, J., Gibbard, P.L., Hughes, P.D. (Eds.), Developments in Quaternary Science, vol. 15. Elsevier, Amsterdam, The
Netherlands, pp. 1065-1074.

Lamb, H.F., Duigan, C.A., Gee, J.H.R., Kelts, K., Lister, G., Maxted, R.W., Merzouk, A., Niessen, F., Tahri, M., Whittington, R.J., Zeroual, E., 1994. Lacustrine sedimentation in a high altitude, semi-arid environment: the palaeolimnological record of Lake Isli, High Atlas, Morocco. In: Millington, A.C., Pye, K. (Eds.), Effects of Environmental Change in Drylands. Wiley, pp. 147-161.

Lancaster, N., Kocurek, G., Singhvi, A., Pandey, V., Deynoux, M., Ghienne, J.-F., Lo, K., 2002. Late Pleistocene and Holocene dune activity and wind regimes in the western Sahara Desert of Mauritania. Geology 30, 991-994.

Lavé, J., Avouc, J.P., 2001. Fluvial incision and tectonic uplift across the Himalayas of central Nepal. J. Geophys. Res. 106, 26561-26591.

Leopold, L.B., Wolman, M.G., Miller, J.P., 1964. Fluvial Processes in Geomorphology. Freeman, San Francisco, p. 522.

Lewin, J., Gibbard, P.L., 2010. Quaternary river terraces in England: forms, sediments and processes. Geomorphology 120, 293-311.

Littmann, T., Schmidt, K.-H., 1989. The response of different relief units to climatic change in an arid environment (southern Morocco). Catena 16, 343-355.

Macklin, M.G., Fuller, I.C., Lewin, J., Maas, G.S., Passmore, D.G., Rose, J., Woodward, J.C., Black, S., Hamlin, R.H.B., Rowan, J.S., 2002. Correlation of fluvial sequences in the Mediterranean basin over the last $200 \mathrm{ka}$ and their relationship to climate change. Quat. Sci. Rev. 21, 1633-1641.

Martins, A.A., Cunha, P.P., Buylaert, J.-P., Huot, S., Murray, A.S., Dinis, P., Stokes, M. 2010. K-feldspar IRSL dating of a Pleistocene river terrace staircase sequence of the Lower Tejo River (Portugal, western Iberia). Quat. Geochronol. 5, 176-180.

Mather, A.E., Stokes, M., 2017. Bedrock structural control on catchment-scale connectivity and alluvial fan processes, High Atlas Mountains, Morocco. In: Ventra, D., Clarke, L.E. (Eds.), Geology and Geomorphology of Alluvial and Fluvial Fans: Terrestrial and Planetary Perspectives. Geological Society, London, Special Publications, p. 440 (in press).

Mather, A.E., Stokes, M., Griffiths, J.G., 2002. Quaternary landscape evolution: a framework for understanding contemporary erosion, Southeast Spain. Land Degrad. Dev. 13, 89-109.

Mather, A.E., Stokes, M., Whitfield, E., 2017. River terraces and alluvial fans: the case for an integrated Quaternary fluvial archive. Quat. Sci. Rev. 166, 74-90.

Medina, F., Cherkaoui, T.-E., 1991. Focal mechanisms of the Atlas earthquakes, and tectonic implications. Geol. Rundsch 80, 639-649.

Meikle, C.D., Stokes, M., Maddy, D., 2010. Field mapping and GIS visualisation of Quaternary river terrace landforms: an example from the Rio Almanzora, SE Spain. J. Maps 2010, 531-542.

Mercier, N., Hatté, C., Fontugne, M., Reyss, J.-L., Valladas, H., Wengler, L., Brugal, J.-P., Ouammoud, A., Weisrock, A., 2009. Chronology of Upper Pleistocene sequences at Sidi Messaoud (wadi Noun, southwestern Morocco) based on 14C, optical and U-series dating. Quat. Geochronol. 4, 326-334.

Miall, A.D., 1978. Lithofacies types and vertical profile models in braided rivers: a summary. In: Miall, A.D. (Ed.), Fluvial Sedimentology, vol. 5. Canadian Society of Petroleum Geologists Memoir, pp. 597-604.

Michard, A., 1976. Éléments de géologie marocaine. Notes Mém. Serv. Géol. Maroc. 252, 408.

Missenard, Y., Zeyen, H., Frizon de Lamotte, D., Leturmy, P., Petit, C., Sébrier, M., Saddiqi, O., 2006. Crustal versus asthenospheric origin of relief of the Atlas Mountains of Morocco. J. Geophys. Res. 111, B03401.

Montgomery, D.R., 2004. Observations on the role of lithology in strath terrace formation and bedrock channel width. Am. J. Sci. 304, 454-476.

Murray, A.S., Wintle, A.G., 2000. Luminescence dating of quartz using an improved single-aliquot regenerative-dose protocol. Radiat. Meas. 32, 57-73.

Nash, D.J., Smith, R.F., 2003. Properties and development of channel calcretes in a mountain catchment, Tabernas Basin, southeast Spain. Geomorphology 50, $227-250$.

Plaziat, J.-C., Aberkan, M., Ahmamou, M., Choukri, A., 2008. The quaternary deposits of Morocco. In: Michard, A., Saddiqi, O., Chalouan, A., Frizon de Lamotte, D. (Eds.), Continental Evolution: the Geology of Morocco. Structure, Stratigraphy and Tectonics of the Africa-Atlantic-mediterranean Triple Junction, vol. 116. Lecture Notes in Earth Sciences, pp. 359-376.

Prescott, J.R., Hutton, J.T., 1995. Environmental dose rates and radioactive disequilibrium from some Australian luminescence dating sites. Quat. Sci. Rev. 14, 439-448.

Santisteban, J.I., Schulte, L., 2007. Fluvial networks of the Iberian Peninsula: a chronological framework. Quat. Sci. Rev. 26, 2738-2757.

Schulz, O., Busche, H., Benbouziane, A., 2008. Decadal precipitation variances and reservoir inflow in the semi-arid Upper Drâa basin (South-Eastern Morocco). In: Zereini, F., Hötzl, H. (Eds.), Climatic Change and Water Resources in the Middle East and North Africa. Springer, Heidelberg, pp. 165-178.

Sébrier, M., Siame, L., Zouine, E.M., Winter, T., Missenard, Y., Leturmy, P., 2006 Active tectonics in the moroccan high atlas. Compt. Rendus Geosci. 338, 65-79.

Stäblein, G., 1988. Geomorphological aspects of the quaternary evolution of the Ouarzazate Basin, Southern Morocco. Lect. Notes Earth Sci. 15, 433-443.

Starkel, L., 2003. Climatically controlled terraces in uplifting mountain areas. Quat. Sci. Rev. 22, 2189-2198.

Stokes, M., Mather, A.E., 2015. Controls on modern tributary-junction alluvial fan occurrence and morphology: high Atlas Mountains, Morocco. Geomorphology 248, 344-362.

Stokes, M., Mather, A.E., Harvey, A.M., 2002. Quantification of River-capture Induced Base-level Changes and Landscape Development, Sorbas Basin, SE Spain, vol. 191. Geological Society, London, Special Publications, pp. 23-35.

Stokes, M., Cunha, P.P., Martins, A.A., 2012a. Techniques for analysing Late Cenozoic 
river terrace sequences. Geomorphology 165, 1-6.

Stokes, M. Griffiths, J.S., Mather, A., 2012b. Palaeoflood estimates of Pleistocene coarse grained river terrace landforms (Río Almanzora, SE Spain). Geomorphology 149, 11-26.

Stokes, M., Mather, A.E., Belfoul, A., Farik, F., 2008. Active and passive tectonic controls for transverse drainage and river gorge development in a collisional mountain belt (Dadès Gorges, High Atlas Mountains, Morocco). Geomorphology $102,2-20$.

Tesón, E. Teixell, A. 2008. Sequence of thrusting and syntectonic sedimentation in the eastern Sub-Atlas thrust belt (Dadès and Mgoun valleys, Morocco). Int. J. Earth Sci. 97, 103-113.

Teixell, A., Arboleya, M.-L., Julivert, M., 2003. Tectonic shortening and topography in the central High Atlas (Morocco). Tectonics 22, 1-13.

Thiel, C., Buylaert, J.-P., Murray, A., Terhorst, B., Hofer, I., Tsukamoto, S., Frechen, M., 2011. Luminescence dating of the Stratzing loess profile (Austria) - testing the potential of an elevated temperature post-IR IRSL protocol. Quat. Int. 234, $23-31$.

Tjallingii, R., Claussen, M., Stuut, J.-B.W., Fohlmeister, J., Jahn, A., Bickert, T., Lamy, F. Röhl, U., 2008. Coherent high- and low-latitude control of the northwest African hydrological balance. Nat. Geosci. 10, 670-675.

Valero-Garcés, B., Zeroual, E., Kelts, K., 1998. Arid phases in the western Mediterranean region during the last glacial cycle reconstructed from lacustrine records. In: Benito, G., Baker, V.R., Gregory, K.J. (Eds.), Palaeohydrology and Environmental Change. John Wiley and Sons Ltd., pp. 67-80

Vandenberghe, J., 2015. River terraces as a response to climatic forcing: formation processes, sedimentary characteristics and sites for human occupation. Quat. Int. 370, 3-11.
Vandenberghe, J., Maddy, D., 2001. The response of river systems to climate change. Quat. Int. 79, 1-3.

Wang, X., Van Balen, R., Yi, S., Vandenberghe, J., Lu, H., 2014. Differential tectonic movements in the confluence area of the Huang Shui and Huang He rivers (Yellow River), NE Tibetan Plateau, as inferred from fluvial terrace positions. Boreas 43, 469-484.

Warme, J.E., 1988. Jurassic carbonate facies of the central and Eastern High Atlas rift, Morocco. Lect. Notes Earth Sci. 15, 169-199.

Weisrock, A., Wengler, L., Mathieu, J., Ouammou, A.,Fontugne, M., Mercier, N. Reyss, J.-L., Valladas, H., Guery, P., 2006. Upper Pleistocene comparative OSL, U/ Th and $14 \mathrm{C}$ datings of sedimentary sequences and correlative morphodynamical implications in the South-Western Anti-Atlas (Oued Noun, $29^{\circ}$ N, Morocco). Quaternaire 17, 45-59.

Weissel, J.K., Seidl, M.A., 1997. Influence of rock strength properties on escarpment retreat across passive continental margins. Geology 25, 631-634.

Westaway, R. Aït Hssaine, A., Demir, T., Beck, A.,2009. Field reconnaissance of the Anti-Atlas coastline, Morocco: fluvial and marine evidence for Late Cenozoic uplift. Glob. Planet. Change 68, 297-310.

Whipple, K.X., Hancock, G.S., Anderson, R.S., 2000. River incision into bedrock: mechanics and relative efficacy of plucking, abrasion and cavitation. Geol. Soc. Am. Bull. 112, 490-503.

Wiche, K., 1953. Klimamorphologische und talgeschichtliche Studien im M'Goungebiet. In: Mitt. Der Geographischen Ges. Wien, vol. 95, pp. 4-41.

Wintle, A.G., Murray, A.S., 2006. A review of quartz optically stimulated luminescence characteristics and their relevance in single-aliquot regeneration dating protocols. Radiat. Meas. 41, 369-391. 